\title{
PUSH FACTORS AND CAPITAL FLOWS \\ TO EMERGING MARKETS: \\ WHY KNOWING YOUR LENDER \\ MATTERS MORE THAN FUNDAMENTALS
}

Eugenio Cerutti, Stijn Claessens, and Damien Puy

NO. 528

November 2017
ADB ECONOMICS WORKING PAPER SERIES 


\section{Push Factors and Capital Flows to Emerging Markets: Why Knowing Your Lender Matters More Than Fundamentals}

\author{
Eugenio Cerutti, Stijn Claessens, \\ and Damien Puy
}

No. 528 | November 2017
Eugenio Cerutti (ecerutti@imf.org) is Assistant to the Director at the Research Department of the International Monetary Fund (IMF). Stijn Claessens

(stijn.claessens@bis.org) is Head of Financial Stability Policy, Monetary and Economic Department of the Bank for International Settlements and formerly of the IMF, where some of the work for this paper was done. Damien Puy (dpuy@imf.org) is Economist at the Research Department of the IMF.

The authors are grateful to Valerie Cerra, Giovanni Dell'Ariccia, Jose Rodriguez Delgado, Paul Hiebert, Johannes Weigand, Sophia Zhang, and participants in seminars at the IMF, the Federal Reserve Board, ETH Zurich, the 10th annual seminar on "Risk, Financial Stability and Banking" of the Banco Central de Brasil, and the 2016 ADB-UNSW International Conference on "Financial Cycles, Systemic Risk, Interconnectedness, and Policy Options for Resilience" for useful comments, and to Yangfan Sun and Haonan Zhou for extensive help with the data. This paper was one of the references used in the Asian Economic Integration Report 2017 theme chapter entitled "The Era of Financial Interconnectedness: How Can Asia Strengthen Financial Resilience?” A similar version of this paper was also issued as IMF Working Paper $15 / 127$. The opinions expressed herein are solely the responsibility of the authors and should not be interpreted as reflecting those of the IMF, the Bank for International Settlements or anyone else associated with these institutions or their policies. 
(C) 2017 Asian Development Bank

6 ADB Avenue, Mandaluyong City, 1550 Metro Manila, Philippines

Tel +632632 4444; Fax +6326362444

www.adb.org

Some rights reserved. Published in 2017

ISSN 2313-6537 (Print), 2313-6545 (electronic)

Publication Stock No. WPS179146-2

DOI: http://dx.doi.org/10.22617/WPS179146-2

The views expressed in this publication are those of the authors and do not necessarily reflect the views and policies of the Asian Development Bank (ADB) or its Board of Governors or the governments they represent.

ADB does not guarantee the accuracy of the data included in this publication and accepts no responsibility for any consequence of their use. The mention of specific companies or products of manufacturers does not imply that they are endorsed or recommended by ADB in preference to others of a similar nature that are not mentioned.

By making any designation of or reference to a particular territory or geographic area, or by using the term "country" in this document, $A D B$ does not intend to make any judgments as to the legal or other status of any territory or area.

This work is available under the Creative Commons Attribution 3.0 IGO license (CC BY 3.0 IGO)

https://creativecommons.org/licenses/by/3.0/igo/. By using the content of this publication, you agree to be bound by the terms of this license. For attribution, translations, adaptations, and permissions, please read the provisions and terms of use at https://www.adb.org/terms-use\#openaccess

This CC license does not apply to non-ADB copyright materials in this publication. If the material is attributed to another source, please contact the copyright owner or publisher of that source for permission to reproduce it. $A D B$ cannot be held liable for any claims that arise as a result of your use of the material.

Please contact pubsmarketing@adb.org if you have questions or comments with respect to content, or if you wish to obtain copyright permission for your intended use that does not fall within these terms, or for permission to use the ADB logo.

Notes:

In this publication, "\$” refers to US dollars.

Corrigenda to ADB publications may be found at http://www.adb.org/publications/corrigenda 


\section{CONTENTS}

TABLES AND FIGURES

ABSTRACT

$\begin{array}{ll}\text { I. INTRODUCTION } & 1\end{array}$

II. DATA AND METHODOLOGY 4

A. Data Set $\quad 4$

B. $\quad$ Econometric Framework $\quad 7$

$\begin{array}{lr}\text { III. } & \text { RESULTS }\end{array}$

A. Factor Estimations, Factor Loadings, and Variance Decompositions 9

B. What Drives the Emerging Market Common Dynamics? 12

C. What Drives the Impact of Global Push Factors across Countries?

D. Robustness 16

IV. $\quad$ CONCLUSION AND POLICY IMPLICATIONS

$\begin{array}{ll}\text { APPENDIXES } & 23\end{array}$

$\begin{array}{lr}\text { REFERENCES } & 29\end{array}$ 


\section{TABLES AND FIGURES}

\section{TABLES}

$1 \quad$ Sample of Countries

2 Summary of Explanatory Variables for Market Characteristics $\quad 7$

3 Variance Decomposition Results 10

$4 \quad$ Finding the Drivers of the Estimated Emerging Market Common Factors 14

$5 \quad$ Explaining Countries' Sensitivities to Push Factors 19

6 Bayesian Averaging Results $\quad 20$

A1.1 Variable Definitions, Frequency, and Sources 24

A1.2 Raw Statistics $\quad 26$

\section{FIGURES}

$1 \quad$ Inflows to Emerging Markets-BOP Raw Data, Aggregated for 34 Emerging Markets 5

2 Common Emerging Markets Factors-Gross versus Disaggregated Flows 9

3 Estimated Betas $\quad 12$

$4 \quad$ Estimated Common Factor in Total Gross Inflows versus VIX 15

5 The Model versus the Global Financial Crisis, and versus the Taper Tantrum 17

6 Institutional Quality versus Correlations 21 


\begin{abstract}
This paper analyzes the behavior of gross capital inflows across 34 emerging markets (EMs), including eight Asian economies. We first confirm that aggregate inflows to EMs comove considerably. Three findings are reported: (i) the aggregate comovement conceals significant heterogeneity across asset types as only bank-related and portfolio bond and equity inflows comove; (ii) while global push factors in advanced economies mostly explain the common dynamics, their relative importance varies by type of flow; and (iii) the sensitivity to common dynamics varies significantly across borrower countries, with market structure characteristics (especially the composition of the foreign investor base and the level of liquidity) rather than a borrower country's institutional fundamentals strongly affecting sensitivities. Countries relying more on international funds and global banks are found to be more sensitive to push factors. Our findings suggest that EMs need to closely monitor their lenders and investors to assess their inflow exposures to global push factors.
\end{abstract}

Keywords: capital flows, emerging markets, global banks, mutual funds, push factors

JEL codes: F32, F36, G11, G15, G23 


\section{INTRODUCTION}

Episodes of large, widespread waves of nonresident capital flowing to and from emerging markets (EMs) over the past decade continue to emphasize the importance of common factors in driving global capital flows. Following and extending the findings of Calvo, Leiderman, and Reinhart $(1993,1996)$ and related literature (among many others, Chuhan, Claessens, and Mamingi 1998), a number of recent papers have documented how global conditions can drive capital flows by nonresidents (gross inflows) to EMs, even more so than for advanced economies (e.g., Forbes and Warnock 2012; Fratzscher 2011). In the past few years, unconventional monetary policy in several advanced economies has been found to have driven much of the bond and equity inflows to EMs (e.g., Fratzscher, Lo Duca, and Straub 2013; IMF 2013a, $2013 \mathrm{~b})$. Although the importance of different push factors varies across studies, a consensus has emerged on the role of United States (US) monetary policy, the supply of global liquidity (especially in US dollars), and global risk aversion (Milesi-Ferretti and Tille 2011, Shin 2012, and Rey 2013, among others) in helping explain the high synchronicity of capital flows to EMs.

However, the literature has made less progress in understanding the mechanisms by which global factors impact EM capital inflows and how they do so differently across EMs. The sudden (and unexpected) deterioration in financial conditions in EMs during the so-called taper tantrum around May 2013 illustrated that not all EMs were equally exposed to changes in global conditions. ' While almost all EMs experienced outflows during this episode, some were much less affected than others (Sahay et al. 2014). Shaghil, Coulibaly, and Zlate (2014) showed that this differentiation across EMs was not unique to the 2013 episode. This naturally raises the question of the reasons behind such heterogeneous responses. Why are some EMs more sensitive to push factors than others? Put differently, when economic and financial conditions in core countries change, why do some EMs always profit (or lose) more than others?

The expected normalization of monetary policy in the US in the near future has made these questions highly relevant for policy makers; in particular those in EMs. Unfortunately, as it stands, the current literature yields inconclusive and at times conflicting results. Some empirical evidence points to the importance of borrowers' macroeconomic and institutional fundamentals in dampening the effect of push factors. Ghosh et al. (2014), who focused on the determinants of surges in inflows to EMs, found that while global factors act as gatekeepers, local fundamental factors determine the final magnitude of the surge. In particular, macroeconomic fundamentals, such as external financing needs, capital account openness, and exchange rate regime, shape the final magnitude. Prachi et al. (2014) and Shaghil, Coulibaly, and Zlate (2014) found that during the tantrum episode, countries with better macroeconomic fundamentals (such as stronger fiscal balance, higher reserves or deeper financial markets) suffered less deterioration in exchange rates, equity prices, and bond yields.

In contrast, Aizenman, Binici, and Hutchison (2014) found that tapering over the very short term (24 hours following the announcement) was associated with a sharper deterioration of financial conditions in robust EMs than in fragile ones. Similarly, Eichengreen and Gupta (2014) did not find that better macroeconomic fundamentals (e.g., lower public debt, higher reserves, or higher economic growth) provided insulation during the tantrum episode. Rather, larger markets experienced more pressures, as investors were better able to rebalance their portfolios in such countries given their relatively large and liquid financial markets.

\footnotetext{
Taper tantrum refers to the 2013 surge in US Treasury yields, which resulted from the Federal Reserve's use of tapering to gradually reduce the amount of money it was feeding into the economy. In reaction to news of this tapering, investors panicked and drew their money rapidly out of the bond market, thereby drastically increasing bond yields.
} 
As such, the relative role of fundamental versus other financial market factors in affecting how global factors drive capital flows to EMs is still an open question. In part, the lack of consensus arises from different methodologies. With the exception of Ghosh et al. (2014), recent studies have focused on the dynamics of prices in-rather than flows to-recipient markets and have restricted their attention to very short-lived episodes of financial stress. And although Ghosh et al. (2014) studied flows, the authors restricted their attention to net capital flows, which, as the authors emphasized, follow very different dynamics from gross flows, and do not lead to the same policy conclusions. As a result, the empirical literature, in its current state, does not allow us to derive general conclusions about the (differential) impact of push factors on capital inflows to EMs.

This paper contributes to this debate by conducting a systematic analysis of the sensitivity of 34 EMs to global push factors using quarterly balance of payments (BOP) data for 2001-2013. To take into account the potential heterogeneity among different types of flows, we analyze total and disaggregated gross inflows separately. We use the standard BOP distinction between foreign direct investment (FDI) flows, portfolio equity flows, portfolio bonds flows, and other investment $(\mathrm{OI})$ to banks and $\mathrm{OI}$ to nonbanks. ${ }^{2}$ After compiling our panel data set, we use a latent factor model in the spirit of Kose et al. (2003) to extract the common dynamics in gross inflows (total and by component) to all EMs. As we will discuss, using a latent factor approach provides a more general way to identify commonality and avoids having to determine which specific factors drive the commonality. Interestingly, although we do show that the commonality identified this way relates in expected ways to the traditional push factors emphasized in the literature, we also find that typical observed proxies, such as the volatility index (VIX), can capture only a small fraction of the actual comovement we observe in the data. After estimating these common dynamics, we then study how the different EMs react to deviations in these (assetspecific) common factors.

Very generally, our results confirm the main findings in the literature. In particular, we find that gross inflows to EMs comove greatly across countries as a result of global (push) factors, and that the magnitude of these effects varies substantially across countries (see Koepke 2015 for a recent review). At the same time, our findings qualify these results in several important respects. First, we find that aggregate comovement conceals significant heterogeneity across asset types. Although bank-related and portfolio bond and equity inflows comove substantially across EMs, FDI, and OI to nonbanks do not. $^{3}$ In addition, while traditional global push factors identified in the literature, such as US monetary policy, global liquidity, or risk aversion, help explain these common dynamics, their relative importance varies greatly by type of flow.

Second and more importantly, we find that the sensitivity to the common dynamics varies greatly across countries and within countries across different type of flows. Whereas some EMs display very low sensitivity to common dynamics in all types of flows, others, such as Brazil, Indonesia, South Africa, Thailand, and Turkey, are highly sensitive in all types. Another group, including countries such as India, Mexico, Pakistan, and the Philippines displays high sensitivity in only one type (or two). Examining

2 Consistent with the residence criterion of balance of payments statistics, we use the term capital "inflows" to refer to changes in the financial liabilities of a domestic country vis-à-vis nonresidents. As such, inflows can be positive and negative during any given quarter as nonresidents can increase or reduce their financial exposures to a given country. Separately, residents can engage in "outflows," i.e., change their net investment position abroad, which can be positive when they build up asset abroad, or negative when they run down assets. We do not analyze these resident outflows as we are interested in the factors driving international investors' behavior vis-à-vis the country. The breakdown of Ol into banks and nonbanks follows Milesi-Ferretti and Tille (2011), where OI to banks captures those Ol transactions or holdings with banks as the domestic counterpart.

3 This is important since FDI constitutes the largest share of capital inflows in the EMs under study. 
the sources of this heterogeneity, we find that financial market characteristics, such as liquidity in the recipient country and composition of the foreign investor bases, rather than macroeconomic or institutional fundamentals, most robustly explain the sensitivities. In line with Aizenman, Binici, and Hutchison (2014) and Eichengreen and Gupta (2014), we do not find that good fundamentals, in the form of high quality of institutions or low public debt, tend to provide insulation. Only in the case of portfolio bond inflows, do we find some macroeconomic fundamentals playing a statistically significant role. Countries with lower reserves, higher trade openness, and more flexible foreign exchange regimes tend to be more sensitive to global push factors. In the case of equity flows, we also find that the depth (or liquidity) of the local market plays a significant role in shaping the impact of global push factors, with liquid markets being substantially more sensitive to changes in global conditions. Finally, after controlling for all these characteristics, we find a strong and consistent role for the composition of the foreign investor base. Across bond, equity, and bank flows, we show that countries relying more on international funds (e.g., mutual funds and exchange-traded funds) and global banks among their nonresident investors are significantly more sensitive to global push factors. ${ }^{4}$ Overall, our findings suggest that EMs with deep financial markets and a high exposure to fickle investors, rather than those with more sound institutional or macroeconomic fundamentals, should expect to receive (or lose external funding when financial conditions in advanced economies improve (or deteriorate).

Our findings contribute to the literature in several respects. We are naturally connected to the literature on push factors and their impacts on EMs (see Forbes and Warnock 2012 for a review), although we rely on a different methodology. The use of latent factors (rather than observed proxies) to capture the true comovement in inflows circumvents the problem of choosing specific global factors whose significance has been found to vary widely across studies and samples. ${ }^{5}$ In fact, we find that the estimated factors tend to capture a much greater part of the comovement than traditional observed variables do (such as the VIX). Also, contrary to most contributions in this field, our analysis largely relies on disaggregated inflows. Besides highlighting the wide heterogeneity in the behavior of different types of flows, this approach makes clear that the sensitivity of EMs to push factors is not universal and identical across flows. In fact, most EMs are found to be exposed to push factors through one or two components only.

Second, our findings on the important roles of financial market characteristics for various types of inflows link to recent findings on the procyclical behavior of global investors, and related impact on the variability of EMs' external funding. As documented by Bruno and Shin (2015a and 2015b), large, international banks expand and contract their cross-border claims in part in response to monetary policy in advanced economies, notably in the US. As the global supply of credit expands (contracts), it tends to be directed at the margin toward (away from) EMs. Related, financial markets in economies more internationalized and with a larger foreign (bank) presence, which typically are EMs, have been found to be more affected by global monetary policy conditions (Cetorelli and Goldberg 2012a). ${ }^{6}$

4 We do want to emphasize that this finding does not mean that borrowers' fundamentals do not matter in shaping other properties of capital flows to EMs. As many contributions have convincingly shown (e.g., Alfaro, Kalemli-Ozcan, and Volosovych 2008), countries with poorer macroeconomic or institutional fundamentals tend to receive less capital inflows. We can confirm this result for our EM sample. Different from this "level" effect, however, our study concerns EMs' sensitivities to global push factors, where our findings suggest that the traditional "push factor" debate may have overstated the importance of fundamentals in shaping countries' sensitivities at the expense of other important determinants.

5 Even though the US VIX is often used as a proxy of global push factors, several papers have highlighted that this variable is often not statistically significant outside the global financial crisis, when it does not vary as much.

6 Cetorelli and Goldberg (2012b), Cerutti and Claessens (2014), Claessens and van Horen (2014) and others have shown that in periods of acute stress, global banks can play a large role in transmitting stress to emerging market economies, as during the 2007-2009 financial crisis. 
As far as portfolio flows are concerned, investors such as mutual funds have been found to transmit shocks in advanced economies to a wide range of markets, and largely independently of the state of fundamentals. Raddatz and Schmukler (2012) and Puy (2013) have found that international fund flows, in particular for EMs, tend to be highly procyclical, with funds reducing their exposure to all countries when financial conditions deteriorate at home (i.e., in advanced markets), and increasing their exposure when conditions at home improve. Using data on global mutual funds, Jotikasthira, Lundblad, and Ramadorai (2012) also have found that funding shocks originating in advanced economies, i.e., where funds are domiciled, translate into fire sales (and purchases) for countries included in the portfolios, in particular for EMs. Although the behavior of specific classes of global investors (banks or funds) is now well documented and has been receiving increasing attention from policy makers, we are the first, to our knowledge, to show that the type of investor base and the state of development of the local financial markets importantly shape the responses to global monetary and financial developments for specific flows to EMs.

The rest of the paper proceeds as follows. Section II describes the data and the empirical methodology we use. Section III presents the results and puts our analysis in the context of existing theoretical and empirical literature. Section IV provides some robustness checks. The last section concludes with broader lessons and outstanding issues for policy and research.

\section{DATA AND METHODOLOGY}

This section introduces the dependent and independent variables we use and the various country characteristics we explore to explain the sensitivities of specific type of inflows to EMs to common dynamics. It also describes the econometric methodology.

\section{A. Data Set}

We study gross capital inflows to EMs with data obtained from the International Monetary Fund's Balance of Payment database, which cover transactions by foreign residents (a resident of the rest of the world) in a country's domestic financial instruments. ${ }^{7}$ These capital inflows data are reported both in total and by their components: FDI flows, portfolio equity flows, portfolio bonds flows, $\mathrm{OI}$ to banks and OI to nonbanks. FDI involves a controlling claim in a company (a stake of at least 10\%), either by the setting up of new foreign operations or the acquisition of a company from a domestic owner. Portfolio investment covers holdings of bonds and equity that do not lead to a controlling stake. OI includes a broad residual array of transactions/holdings between residents and nonresidents, such as loans, deposits, trade credits and the like. Within this category, following Milesi-Ferretti and Tille (2011), we separate out those transactions or holdings in which the domestic counterpart is a bank from other counterparts.

We focus on quarterly capital inflows during Q12001-Q42013 for a set of 34 EMs (see Table 1 for the exact sample of countries). All series are measured in US dollars and normalized by the recipient country gross domestic product (GDP) (also measured in US dollars at a quarterly frequency). ${ }^{8}$ As an

7 Foreign investors' transactions, because of their volume and volatility, tend to affect heavily EM economic conditions (exchange rate, current account) and have therefore attracted most of the attention in the empirical literature (see for instance Broner et al. 2013).

8 Even though BOP data are available before 2001, we start our analysis in early 2000s since it is also based on other capital inflow data set (e.g., Emerging Portfolio Fund Research [EPFR] fund flows), which do not have consistent coverage before the 2000s. 
illustration, Figure 1 reports the (total) gross inflows to the 34 EMs in our sample over the period, where flows are expressed as a percentage of the aggregate GDP of the 34 countries.

Table 1: Sample of Countries

\begin{tabular}{llll}
\hline Latin America & \multicolumn{1}{c}{ Asia } & Emerging Europe & Other \\
\hline Argentina & India & Belarus & Turkey \\
Brazil & People's Republic of China & Kazakhstan & South Africa \\
Chile & Indonesia & Bulgaria & Israel \\
Colombia & Republic of Korea & Russian Federation & \\
Mexico & Malaysia & Ukraine & \\
Peru & Pakistan & Czech Republic & \\
Uruguay & Philippines & Slovak Republic \\
Bolivarian Republic of Venezuela & Thailand & Estonia & \\
& & Latvia & \\
& & Hungary & \\
& & Lithuania & \\
& & Croatia & \\
& & Slovenia & \\
& & Poland & Romania \\
\hline
\end{tabular}

Source: Authors' compilation.

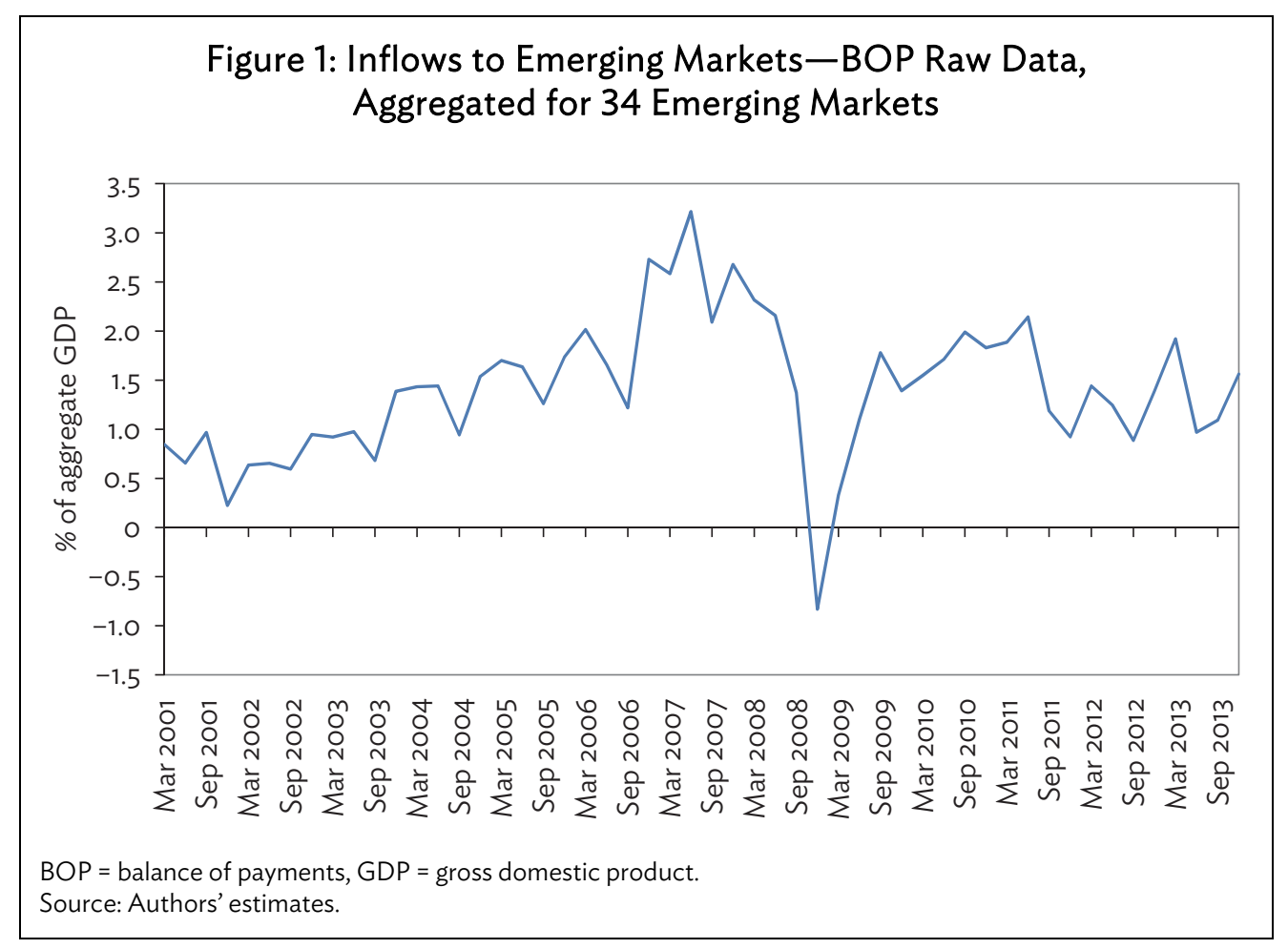

The explanatory variables used in this paper fall in two broad categories: (i) variables that are used to identify push and pull factors, and (ii) variables capturing fundamentals and market characteristics that are used to evaluate the determinants behind EM sensitivities to the same push 
factors. Variables in each group are presented below while definitions, sources, frequency, and summary statistics are reported in Appendix Tables A1.1 and A1.2.

In the case of push factors, we follow the literature and use the following variables: (i) the average GDP growth rate in four core economies (the euro area, Japan, the United Kingdom, and the US); (ii) the US VIX; (iii) changes in the expected US policy rate; (iv) the slope of the US yield curve (the difference between 10-year and the 3-month US government T-bill yields); and ( $v$ ) the real effective exchange rate (REER) in the US. We also use push variables that are potentially specific to some types of capital inflows. For banking inflows, we use the US dealer bank leverage and TED spread (the difference between short-term interbank lending and government T-bill rates) to capture global banks' leverage and funding conditions. For bond inflows, we use the 10-year US government bond yield, which captures the cost of investing in cross-border bonds compared to the cost of investing in US bonds; and the (lagged) return of the JPMorgan Emerging Market Bond Index (EMBI) as a proxy for return-chasing in EM bond markets. For equity inflows, we use the (lagged) return in the MSCI Emerging Markets Index, to capture equity return-chasing in portfolio equity inflows.

To control for the presence of potential pull variables that are common to all EMs, we use an index of aggregate commodity prices and the (lagged) aggregate real GDP growth in EMs.

In the case of fundamentals and market characteristics, we follow once again existing literature. Macroeconomic fundamentals are captured by a country's trade openness, i.e., exports and imports as a percentage of GDP, the level of public debt (as a percentage of GDP), foreign exchange reserves (as a percentage of GDP), the foreign exchange regime (fixed versus the degree of floating), and its average real GDP growth rate. Institutional quality has a proxy in the International Country Risk Guide rule of law and investor protection indexes.

In contrast with the existing literature, however, we go further in assessing the financial characteristics of recipient markets. For each recipient country, and whenever possible, we assess the following four dimensions: (i) the degree of foreign openness, (ii) the size of the market, (iii) the liquidity of the market, and (iv) the composition of the foreign investor base. We identify proxy variables for each of these dimensions, with the exception of a liquidity measure for the market of $\mathrm{Ol}$ to banks inflows, which is not applicable. For presentational simplicity, the table below summarizes the variables used for each dimension and type of flows, while Appendix A provides a detailed discussion of each variable.

Although most of the variables used to assess market characteristics are standard in the literature, we put forward some new ones that can serve as a proxy for the importance of some types of investors related to each specific capital inflows (Table 2). In particular, because a decomposition of BOP flows by type of foreign investor is not available, we compute, for each EM and each asset in our sample, the correlation between BOP-recorded inflows on the one hand, and inflows reported directly by specific types of investors on the other. As we do this for each type of flow, three correlations are computed for each country in our sample: (i) the correlation between BOP portfolio equity flows and equity flows coming from international equity funds reported by the financial data company Emerging Portfolio Fund Research (EPFR) Global, (ii) the correlation between BOP portfolio bond flows and bond flows coming from international bond funds reported by EPFR Global, and (iii) the correlation between BOP OI to bank flows and global bank flows reported by the Bank for International Settlements Locational International Banking Statistics. In all cases, we interpret a high correlation as a sign that funds and global banks account for most of the movements in capital inflows to (or out of) the given economy. For further details on the EPFR Global and Bank for International Settlements data sets, their coverage and how they relate to BOP-recorded flows, see Appendix B. 
Table 2: Summary of Explanatory Variables for Market Characteristics

\begin{tabular}{|c|c|c|c|c|}
\hline & $\begin{array}{l}\text { Foreign } \\
\text { Openness }\end{array}$ & Size & Liquidity & $\begin{array}{l}\text { Composition of the Foreign } \\
\text { Investor Base }\end{array}$ \\
\hline \multirow{2}{*}{$\begin{array}{l}\text { Equity } \\
\text { Market }\end{array}$} & \multirow{2}{*}{$\begin{array}{l}\text { Stock of foreign } \\
\text { equity funding/ } \\
\text { GDP }\end{array}$} & $\begin{array}{l}\text { Local size: Stock market } \\
\text { capitalization/GDP }\end{array}$ & $\begin{array}{l}\text { Stock market } \\
\text { turnover } \\
\text { (as \% of market } \\
\text { capitalization) }\end{array}$ & $\begin{array}{l}\text { - Share of foreign equity } \\
\text { funding coming from AEs }\end{array}$ \\
\hline & & $\begin{array}{l}\text { Relative to EMs: Stock of } \\
\text { foreign equity in country } i / \\
\text { Total stock of foreign equity } \\
\text { in the } 34 \mathrm{EMs}\end{array}$ & $\begin{array}{l}\text { Listed in } \mathrm{MSCl} \\
\text { benchmark } \\
\text { (emerging or } \\
\text { frontier) }\end{array}$ & $\begin{array}{l}\text { - Correlation of BOP equity } \\
\text { flows with EPFR equity flows }\end{array}$ \\
\hline \multirow[b]{2}{*}{$\begin{array}{l}\text { Bond } \\
\text { Market }\end{array}$} & \multirow[b]{2}{*}{$\begin{array}{l}\text { Stock of foreign } \\
\text { bond funding/ } \\
\text { GDP }\end{array}$} & $\begin{array}{l}\text { Local size: Bond market } \\
\text { capitalization/GDP }\end{array}$ & \multirow[b]{2}{*}{$\begin{array}{l}\text { Listed in EMBI } \\
\text { benchmark }\end{array}$} & $\begin{array}{l}\text { - Share of foreign bond funding } \\
\text { coming from AEs }\end{array}$ \\
\hline & & $\begin{array}{l}\text { Relative to EMs: Stock of } \\
\text { foreign bond in country i/ } \\
\text { Total stock of foreign bond } \\
\text { in the } 34 \text { EMs }\end{array}$ & & $\begin{array}{l}\text { - Correlation of BOP bond } \\
\text { flows with EPFR bond flows }\end{array}$ \\
\hline $\begin{array}{l}\text { Banking } \\
\text { Sector }\end{array}$ & $\begin{array}{l}\text { Stock of foreign } \\
\text { bank claims/GDP }\end{array}$ & Private credit/GDP & & $\begin{array}{l}\text { - Correlation of BOP bank flows } \\
\text { with BIS global bank flows }\end{array}$ \\
\hline
\end{tabular}

$\mathrm{AE}=$ advanced economy, $\mathrm{BIS}=\mathrm{Bank}$ for International Settlements, $\mathrm{BOP}=$ balance of payments, $\mathrm{EM}=$ emerging market, $\mathrm{EMBI}=\mathrm{Emerging}$ Market Bond Index, EPFR = Emerging Portfolio Fund Research, GDP = gross domestic product, $\mathrm{MSCl}=$ Morgan Stanley Capital International.

Source: Authors' compilation.

\section{B. Econometric Framework}

In this section, we build on the methodology introduced by Kose, Otrok, and Whiteman (2003) and estimate the following latent factor model:

$$
y_{i, t}=\beta_{i}^{E M} f_{t}^{E M}+\beta_{i}^{\text {Region }} f_{t}^{\text {Region }}+\varepsilon_{i, t}
$$

where $y_{i, t}$ is the (normalized) inflow of a specific type to country $i$ in quarter $t, f_{t}^{E M}$ is the (unobserved) factor affecting all EMs in our sample at time $t, f_{t}^{\text {Region }}$ is the (unobserved) regional factor affecting all countries belonging to region $j$ at time $t$, and $\beta_{i}^{E M}$ and $\beta_{i}^{\text {Region }}$ designate country-specific factor loadings measuring the responses of country $i$ to the common EM and regional factors, respectively. Finally, $\varepsilon_{i, t}$ is an unobserved country-specific residual factor.

Because we allow factors to follow autoregressive (AR) processes, the model in (1) is in fact a dynamic latent factor model. More precisely, we assume that idiosyncratic factors follow an $\operatorname{AR}(p)$ process:

$$
\varepsilon_{i, t}=\rho_{i, 1} \varepsilon_{i, t-1}+\rho_{i, 2} \varepsilon_{i, t-2}+\cdots+\rho_{i, p} \varepsilon_{i, t-p}+u_{i, t}
$$

where $u_{i, t} \sim N\left(0, \sigma_{i}^{2}\right)$ and $E\left(u_{i, t}, u_{i, t-s}\right)=0$ for $s \neq 0$ and the world and regional factors follow the respective $A R(q)$ processes:

$$
\begin{gathered}
f_{t}^{E M}=\rho_{1} f_{t-1}^{E M}+\rho_{2} f_{t-2}^{E M}+\cdots+\rho_{q} f_{t-q}^{E M}+u_{t}^{E M} \\
f_{j, t}^{\text {Region }}=\rho_{1, j} f_{t-1}^{\text {Region }}+\rho_{2, j} f_{t-2}^{\text {Region }}+\cdots+\rho_{q, j} f_{t-q}^{\text {Region }}+u_{j, t}^{\text {Region }}
\end{gathered}
$$


where $u_{t}^{E M} \sim N\left(0, \sigma_{E M}^{2}\right), u_{j, t}^{\text {Region }} \sim N\left(0, \sigma_{j}^{2}\right)$ and $E\left(u_{t}^{E M}, u_{t-s}^{E M}\right)=E\left(u_{j, t}, u_{j, t-s}\right)=0$ for $s \neq 0$.

Given that the factors are unobservable, standard regression methods do not allow for the estimation of the model. As a consequence, we rely on Bayesian techniques, as in Kose, Otrok, and Whiteman (2003), for the estimation. As is standard in the literature, as a first step, we normalize the sign of the factor/loadings by (i) restricting the loading on the world factor for the first country in our sample to be positive, and (ii) restricting the loadings on the regional factor for one country in each region to be positive. Second, to normalize the scales, we assume that each of the factor variances is equal to 1 . Note that these normalizations do not affect the qualitative results and simply allow the identification of the model. In addition, we use Bayesian techniques with data augmentation to estimate the parameters and factors in (1)-(4). This implies simulating draws from complete posterior distribution for the model parameters and factors and successively drawing from a series of conditional distributions using a Markov Chain Monte Carlo procedure. Posterior distribution properties for the model parameters and factors are based on 300,000 Markov Chain Monte Carlo replications after 30,000 burn-in replications.

Following Kose, Otrok, and Whiteman (2003), we use the following conjugate priors when estimating the model:

$$
\begin{aligned}
& \left(\beta_{i}^{E M}, \beta_{i}^{\text {Region }}\right)^{\prime} \sim N\left(0, I_{2}\right) \\
& \left(\rho_{i, 1}, \ldots, \rho_{i, p}\right)^{\prime} \sim N\left(0, \operatorname{diag}\left(1,0.5, \ldots, 0.5^{p-1}\right)\right) \\
& \left(\rho_{1}, \ldots, \rho_{q}\right)^{\prime} \sim N\left(0, \operatorname{diag}\left(1,0.5, \ldots, 0.5^{q-1}\right)\right) \\
& \left(\rho_{1, j}, \ldots, \rho_{q, j}\right)^{\prime} \sim N\left(0, \operatorname{diag}\left(1,0.5, \ldots, 0.5^{q-1}\right)\right) \\
& \left(\sigma_{i}^{2}\right)^{\prime} \sim I G(6,0.001),
\end{aligned}
$$

where $i=1, \ldots, 34$ and IG denotes the Inverse Gamma distribution, implying a rather diffuse prior on the innovations variance. We also assume that the AR processes in (2)-(4) are stationary. In practice, in our implementation, we set the length of both the idiosyncratic and factor AR polynomials to 2 . However, other (nonzero) values for $p$ and $q$ were tried with no substantial differences in the results. Similarly, reasonable deviations in priors did not generate any notable differences in the results presented below.

Beside estimating the factors, we are particularly interested in measuring the influence of the common EM factor on the different EMs in our sample. As a result, most of the analysis below will focus on explaining the cross-country heterogeneity we observe in (i) factor loadings $\beta_{i}^{E M}$, and (ii) variance decomposition $\theta_{i}^{E M}$, where $\theta_{i}^{E M}$ denotes the share of variance in country i's funding that is attributable to the common EM dynamic. It is computed as follows:

$$
\theta_{i}^{E M}=\frac{\left(\beta_{i}^{E M}\right)^{2} \operatorname{var}\left(f_{t}^{E M}\right)}{\operatorname{var}\left(y_{i, t}\right)}
$$

Intuitively, the $\beta_{i}^{E M}$ loadings measure the contemporaneous impact of a sudden change in the direction of common EM factors for country $i$, whereas the variance decomposition is an estimate of the share of the total variance of country i's funding that can be attributed to the common EM dynamics over the sample period.

Finally, models are estimated using four regions, namely: (i) Latin America, (ii) Asia, (iii) Emerging Europe, and (iv) Other. Table 1 provides the composition of each region. Note that although 
alternative regional decompositions could be used, the key results derived below are not sensitive to these decompositions as we focus on EMs' sensitivity to the common dynamics, captured through the $\beta_{i}^{E M}$ or $\theta_{i}^{E M}$, both of which are invariant to the regional classification.

\section{RESULTS}

This section first presents the results of the factor estimation and discusses the cross-sectional dispersion we observe in the key statistics $-\beta_{i}^{E M}$ and $\theta_{i}^{E M}$-highlighted above. After relating estimated factors to typical observed variables emphasized in the literature, we turn to a discussion of country characteristics to help explain the sensitivities of countries to global factors.

\section{A. Factor Estimations, Factor Loadings, and Variance Decompositions}

The factor decomposition outlined in (1) yields the following three results. First, the model identifies precisely the commonality in (total) aggregated gross capital inflows to all EMs. Second, it shows that using total inflows conceals significant heterogeneity across assets. While portfolio equity flows, portfolio bond flows and $\mathrm{OI}$ to banks do comove across EMs, FDI and OI to nonbanks do not (Figure 2). Actually, with the exception of periods of global instability during which all flows go in the same direction, inflow dynamics can vary greatly across types of assets. This suggests, in turn, that different assets do not respond to the same driving (push or pull) forces, an aspect we analyze further in the next section. Third, the quantitative impact of the common EM dynamics varies a lot across markets and types of flows.

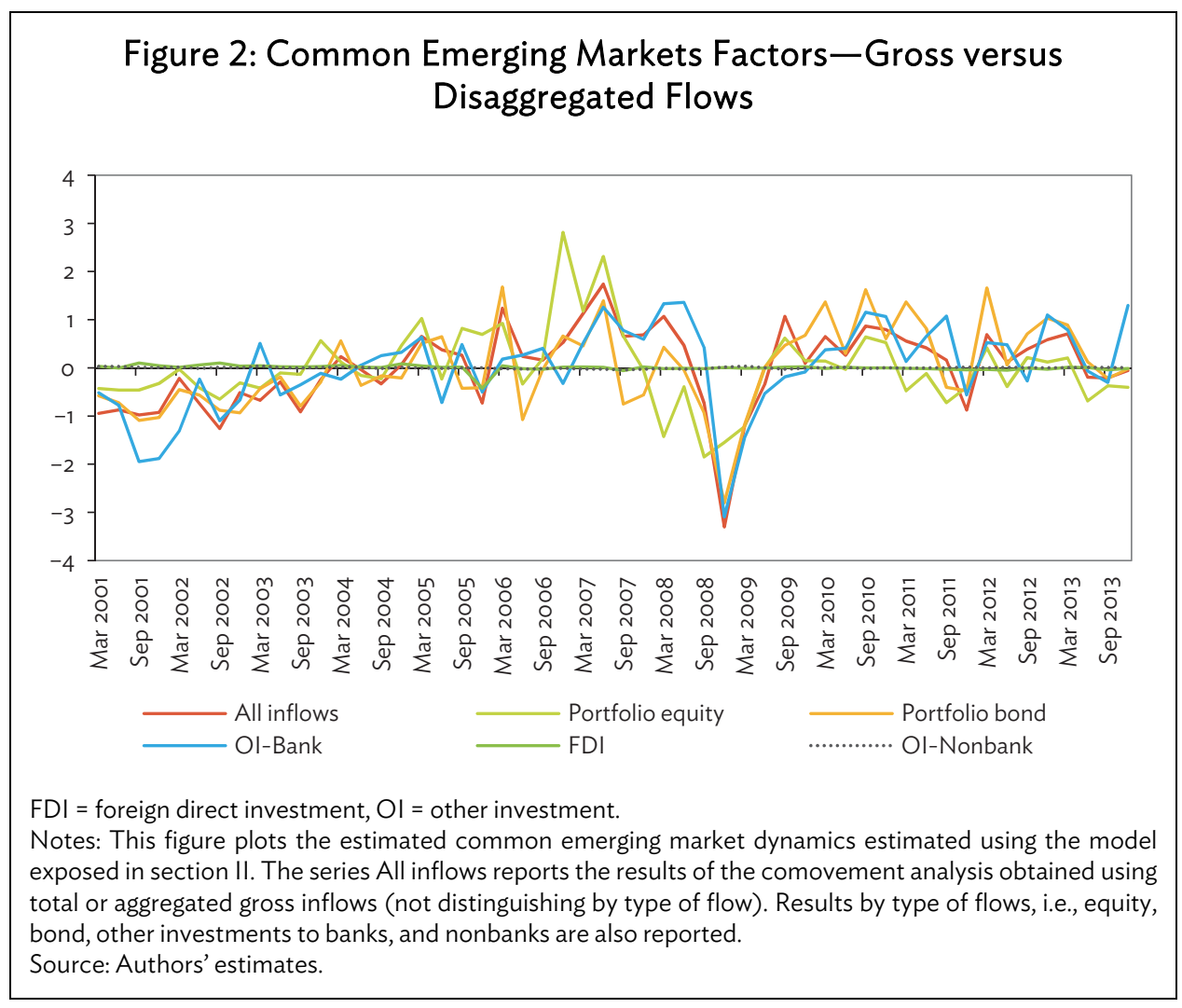


To show the heterogeneity in country responses, Figure 3 reports the $\beta_{i}^{E M}$ coefficients estimated for equity, bond, and bank flows. In the case of equity flows, we find that a unit standard deviation in the common EM factor will generate, on impact, a unit standard deviation in equity flows to Pakistan and a 0.6 standard deviation in equity flows to India. In contrast, countries like Belarus, Estonia, or Latvia do not experience any significant change in their foreign equity funding. Similarly, although bond flows to Indonesia and South Africa react strongly to the common EM factor, bond flows to the People's Republic of China, Colombia, and Bulgaria are almost insensitive to the common dynamics.

Because the variance decompositions are a function of $\beta_{i}^{E M}$, the strong heterogeneity we observe in factor loadings naturally carries over to the variance decompositions. Table 3 reports the share of variance accounted for by the common EM factor and computed using equation (10). Intuitively, this variance decomposition provides a measure of the importance of this factor in driving the external funding of each country over the sample period. Note that because the model was not able to identify precisely any comovement structure in the FDI and OI to nonbank flows to EMs, only the results for portfolio equity and bond flows and $\mathrm{Ol}$ to bank flows, as well as aggregate inflows, are reported.

Table 3 and Figure 3 highlight two important results. First, the impact of the common EM factors is large for a small number of countries-in particular for Asian countries-in the case of equity flows, whereas it is more evenly distributed across EMs for bond and bank flows. Second, substantial heterogeneity exists both across countries and across the different types of assets in the way common EM factors affect external funding. We can broadly identify three groups of EMs. The high sensitivity group contains countries that are relatively sensitive in all components, such as Brazil, Indonesia, South Africa, Thailand, and Turkey. The asymmetric group features countries with a high sensitivity in only one (or two) components, such as Pakistan, the Philippines, India, or Mexico. Finally, the insensitive group includes countries such as Chile, Estonia, and Latvia that display very low relative sensitivity in all components. Interestingly, the highest sensitivities across all asset types are in this group. For instance, in the case of Pakistan and the Philippines, more than half of the variance in equity funding is accounted for by the common EM factor, implying that, to a great extent, both countries receive (or lose) equity funding whenever other EMs do.

Table 3: Variance Decomposition Results

$(\%)$

\begin{tabular}{|c|c|c|c|c|c|c|c|c|}
\hline & \multicolumn{2}{|c|}{ Portfolio Equity } & \multicolumn{2}{|c|}{ Portfolio Bond } & \multicolumn{2}{|c|}{ Ol-Bank } & \multicolumn{2}{|c|}{ All Inflows } \\
\hline & Global & Regional & Global & Regional & Global & Regional & Global & Regiona \\
\hline \multicolumn{9}{|l|}{ Latin America } \\
\hline Argentina & 25 & 7 & 12 & 11 & 29 & 5 & 12 & 20 \\
\hline Brazil & 24 & 4 & 25 & 6 & 25 & 11 & 27 & 5 \\
\hline Chile & 2 & 10 & 2 & 20 & 4 & 4 & 11 & 13 \\
\hline Colombia & 1 & 12 & 1 & 20 & 8 & 6 & 1 & 32 \\
\hline Mexico & 7 & 8 & 29 & 11 & 8 & 32 & 20 & 15 \\
\hline Peru & 3 & 5 & 8 & 2 & 26 & 3 & 34 & 19 \\
\hline Uruguay & 2 & 16 & 18 & 14 & 0 & 8 & 1 & 3 \\
\hline Bolivarian Republic of Venezuela & 0 & 6 & 7 & 6 & 3 & 11 & 3 & 16 \\
\hline Average & 8 & 8 & 13 & 11 & 13 & 10 & 14 & 15 \\
\hline
\end{tabular}


Table 3 continued

\begin{tabular}{|c|c|c|c|c|c|c|c|c|}
\hline & \multicolumn{2}{|c|}{ Portfolio Equity } & \multicolumn{2}{|c|}{ Portfolio Bond } & \multicolumn{2}{|c|}{ Ol-Bank } & \multicolumn{2}{|c|}{ All Inflows } \\
\hline & Global & Regional & Global & Regional & Global & Regional & Global & Regional \\
\hline \multicolumn{9}{|l|}{ Asia } \\
\hline India & 35 & 16 & 4 & 34 & 7 & 2 & 55 & 4 \\
\hline People's Republic of China & 18 & 4 & 2 & 3 & 35 & 7 & 28 & 1 \\
\hline Indonesia & 18 & 8 & 43 & 9 & 23 & 23 & 21 & 8 \\
\hline Republic of Korea & 7 & 12 & 11 & 2 & 19 & 38 & 50 & 12 \\
\hline Malaysia & 18 & 4 & 16 & 6 & 22 & 38 & 39 & 45 \\
\hline Pakistan & 60 & 18 & 13 & 7 & 1 & 2 & 2 & 10 \\
\hline Philippines & 48 & 4 & 11 & 2 & 6 & 2 & 26 & 1 \\
\hline Thailand & 32 & 15 & 17 & 21 & 20 & 7 & 53 & 13 \\
\hline Average & 29 & 10 & 15 & 11 & 16 & 15 & 34 & 12 \\
\hline \multicolumn{9}{|l|}{ Emerging Europe } \\
\hline Belarus & 0 & 0 & 10 & 16 & 7 & 0 & 1 & 3 \\
\hline Kazakhstan & 30 & 2 & 20 & 11 & 1 & 42 & 4 & 34 \\
\hline Bulgaria & 16 & 62 & 1 & 2 & 5 & 38 & 6 & 60 \\
\hline Russian Federation & 8 & 2 & 15 & 3 & 23 & 37 & 36 & 17 \\
\hline Ukraine & 3 & 0 & 11 & 2 & 10 & 68 & 8 & 36 \\
\hline Czech Republic & 1 & 10 & 17 & 10 & 21 & 6 & 1 & 12 \\
\hline Slovak Republic & 1 & 1 & 16 & 3 & 5 & 9 & 0 & 2 \\
\hline Estonia & 1 & 91 & 5 & 2 & 1 & 53 & 6 & 39 \\
\hline Latvia & 1 & 1 & 5 & 46 & 4 & 59 & 11 & 50 \\
\hline Hungary & 1 & 0 & 14 & 3 & 1 & 25 & 1 & 35 \\
\hline Lithuania & 1 & 16 & 12 & 5 & 1 & 75 & 5 & 63 \\
\hline Croatia & 3 & 0 & 1 & 5 & 15 & 2 & 2 & 36 \\
\hline Slovenia & 35 & 1 & 4 & 2 & 5 & 64 & 17 & 40 \\
\hline Poland & 1 & 3 & 22 & 9 & 1 & 24 & 32 & 11 \\
\hline Romania & 30 & 1 & 11 & 10 & 2 & 60 & 8 & 69 \\
\hline Average & 9 & 13 & 11 & 9 & 7 & 38 & 10 & 43 \\
\hline \multicolumn{9}{|l|}{ Other } \\
\hline Turkey & 22 & 20 & 26 & 3 & 37 & 6 & 36 & 5 \\
\hline South Africa & 17 & 14 & 30 & 22 & 22 & 10 & 41 & 18 \\
\hline Israel & 3 & 33 & 13 & 39 & 2 & 53 & 17 & 30 \\
\hline Average & 14 & 22 & 23 & 10 & 20 & 23 & 24 & 29 \\
\hline
\end{tabular}

$\mathrm{OI}=$ other investment.

Notes: This table reports, for each country in our sample, the (mean) of the share of variance accounted for by common and regional factors, as presented in section II. Results for aggregated inflows are reported under the column All Inflows. Results by type of flows are reported under the corresponding column. Source: Authors' estimates. 


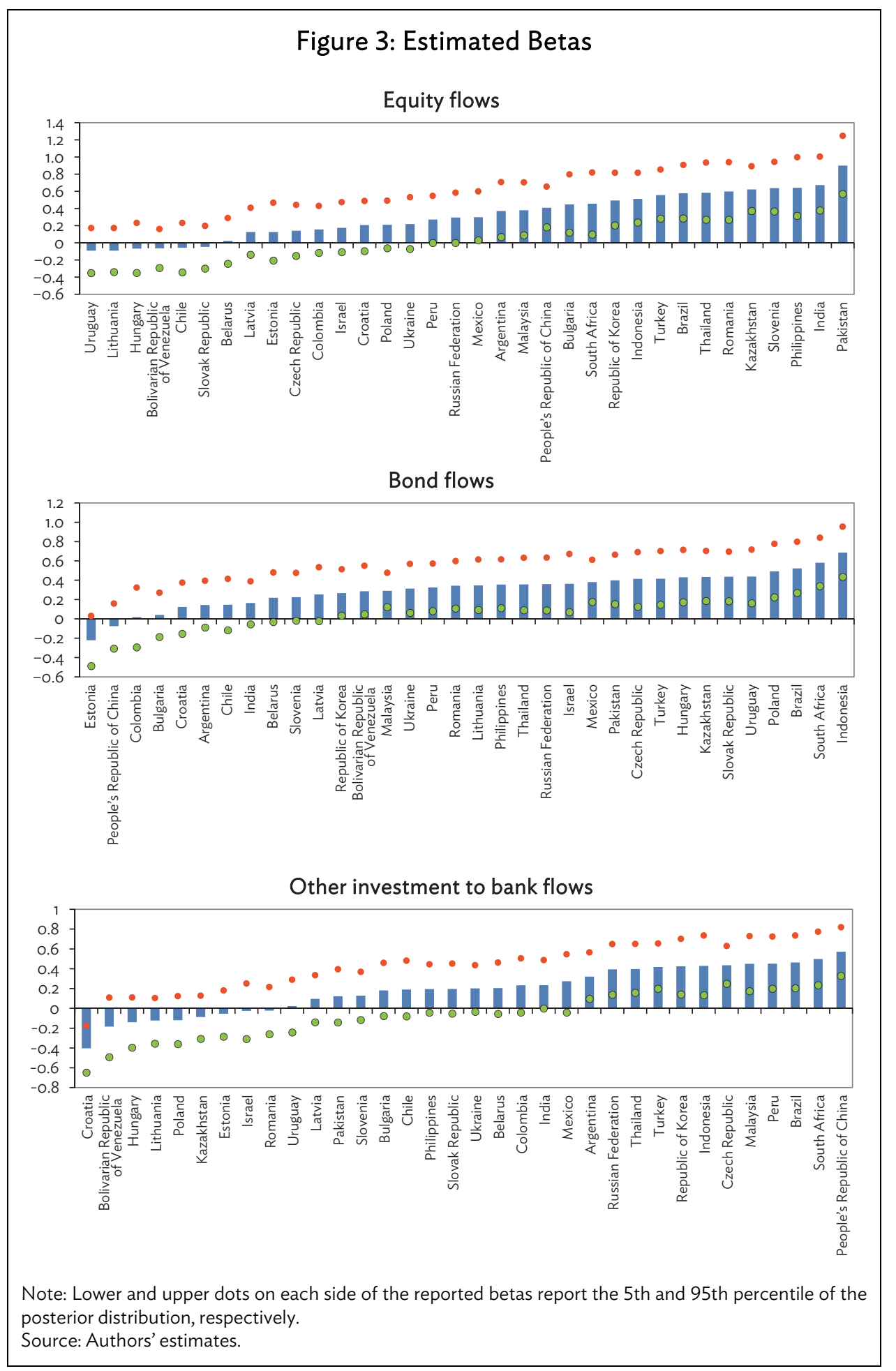

\section{B. What Drives the Emerging Market Common Dynamics?}

In this section, we investigate the role of potential push and pull (internal) factors driving the EM common factors estimated for the aggregate and each type of inflows in the previous section. In this 
context, we estimate the following equations for the EM common factors on aggregated inflows and separately for portfolio bond, portfolio equity, OI to banks:

$$
f_{t}^{E M}=\alpha \text { Push }_{t}+\beta \text { Pull }_{t}+\gamma \text { Type Specific Factors } t+\varepsilon_{t}
$$

where the vectors include the general push, pull, and type-specific variables presented in section II. Given the Q22001-Q42013 coverage of our sample, the total number of observations is 50.

The signs of the coefficients of push variables are expected to be negative. A slowdown in growth in advanced economies leads to an expansion of capital flows to emerging market economies, as investors take advantage of better growth opportunities and higher yields (e.g., Reinhart and Reinhart 2008). An increase in the VIX, i.e., increased uncertainty, is usually associated with a decrease of crossborder flows, as per Rey (2013). Similarly, an increase in the US REER likely reduces cross-border flows since borrowers become riskier and less solvent in US dollar terms as their currencies depreciate, as noted in Bruno and Shin (2015b). A flatter yield curve, reflecting less profitable investment opportunities at home, may also trigger a search for yield abroad. For example, banks, which borrow short term and lend long term, might turn to cross-border investments when the yield curve flattens, as also found by Cerutti, Claessens, and Ratnovski (2014). Finally, higher expected policy rates would reduce crossborder flows to EMs since the opportunity and funding costs are expected to increase for investors. Most of the precrisis literature has used the level of a short-term rate, such as the US policy rate, but, following more recent analysis (e.g., Koepke 2014), we use the change in expected US policy rates, also to deal with the fact that the policy rate has been very stable in recent years.

The expected sign of coefficients attached to commodity prices and to growth in EM economies are both positive. Since many EMs are net exporters of commodities, higher commodity prices improve EMs' economic perspectives and thus likely boost cross-border flows. ${ }^{9}$ With regard to the type- (or asset-) specific factors, the coefficients for return chasing variables and bank leverage are all expected to be positive since a high leverage indicates a lower perceived risk and higher willingness and capacity of banks to lend (Adrian and Shin 2014, Bruno and Shin 2015a).

The actual regression results (Table 4) indicate that almost all coefficients, when statistically significant, have the expected signs. Among the push variables, VIX and REER are the most robust factors behind the commonality in aggregate inflows and in the various types of capital inflows (see columns 1, 5, 9, and 13). In contrast, the slope of the yield curve, the GDP growth rate of core countries, or the expected policy are only significant in some cases. ${ }^{10}$ The explanatory power of the VIX is, however, very much driven by the global financial crisis, as shown in Figure 4. When using pull factors only, we find the price of commodities to be the only significant variable across the various types of capital inflows, with EM growth only significant in the case of OI to bank and total inflows (see columns 2, 6, 10, and 14). When push and pull variables are used simultaneously, the same results are found (see columns 3, 7, 11, and 15). ${ }^{11}$

9 Reinhart and Reinhart (2008) found evidence of a statistically significant and positive relationship between commodity prices and capital inflows between 1967 and 2006.

10 The significant coefficient on Group of Four GDP growth on the bank regression is opposite to the expected one, but it could be capturing the fact that higher growth rates in core economies often tend to increase global bank funding (e.g., more deposits, and the like), which could trigger positive cross-border flows.

1 The only exception is EM GDP growth, which seems to lose explanatory power and even flip signs when used with more variables. It is excluded in some regressions for this reason. 
Table 4: Finding the Drivers of the Estimated Emerging Market Common Factors

\begin{tabular}{|c|c|c|c|c|c|c|c|c|c|c|c|c|c|c|c|c|}
\hline \multirow[b]{2}{*}{ Variables } & \multicolumn{4}{|c|}{ Bank } & \multicolumn{4}{|c|}{ Bond } & \multicolumn{4}{|c|}{ Equity } & \multicolumn{4}{|c|}{ Total } \\
\hline & (1) & (2) & (3) & (4) & (5) & (6) & $(7)$ & (8) & (9) & (10) & (11) & (12) & (13) & (14) & (15) & (16) \\
\hline \multirow[t]{2}{*}{ Core_GDP_Growth } & $0.132^{* * *}$ & & $0.0736^{*}$ & 0.0547 & -0.00808 & & -0.0416 & -0.0308 & 0.0527 & & 0.0588 & 0.0329 & $0.0789^{*}$ & & 0.00857 & -0.0351 \\
\hline & $(0.0387)$ & & $(0.0412)$ & $(0.0426)$ & $(0.0543)$ & & $(0.0583)$ & $(0.0627)$ & $(0.0535)$ & & $(0.0526)$ & $(0.0532)$ & $(0.0418)$ & & $(0.0388)$ & $(0.0417)$ \\
\hline \multirow[t]{2}{*}{ US VIX } & $-0.0313^{* * *}$ & & -0.0161 & 0.00183 & $-0.0516^{* * *}$ & & $-0.0356^{* * *}$ & $-0.0353^{* * *}$ & $-0.0273^{* * *}$ & & $-0.0218^{*}$ & $-0.0232^{*}$ & $-0.0397^{* * *}$ & & $-0.0209^{* *}$ & 0.00264 \\
\hline & $(0.0105)$ & & $(0.0112)$ & $(0.0154)$ & $(0.00997)$ & & $(0.0106)$ & $(0.0104)$ & $(0.00839)$ & & $(0.0130)$ & $(0.0116)$ & $(0.0108)$ & & $(0.00991)$ & $(0.0167)$ \\
\hline \multirow[t]{2}{*}{ Exp. change in policy rate } & -0.117 & & -0.101 & -0.00785 & -0.325 & & -0.194 & -0.198 & 0.0101 & & 0.126 & -0.0690 & $-0.401^{*}$ & & $-0.372^{*}$ & $-0.415^{*}$ \\
\hline & $(0.265)$ & & $(0.232)$ & $(0.253)$ & $(0.289)$ & & $(0.304)$ & $(0.289)$ & $(0.342)$ & & $(0.370)$ & $(0.333)$ & $(0.235)$ & & $(0.214)$ & $(0.206)$ \\
\hline \multirow[t]{2}{*}{ US yield_curve } & -0.0110 & & -0.127 & -0.0374 & 0.118 & & -0.1000 & -0.0131 & $-0.258^{* *}$ & & $-0.392^{* *}$ & $-0.268^{* *}$ & -0.0820 & & $-0.233^{* *}$ & -0.164 \\
\hline & $(0.0702)$ & & $(0.104)$ & $(0.107)$ & $(0.114)$ & & $(0.167)$ & $(0.126)$ & $(0.110)$ & & $(0.147)$ & $(0.108)$ & $(0.0849)$ & & $(0.102)$ & $(0.132)$ \\
\hline & $(0.00995)$ & & $(0.0115)$ & $(0.0188)$ & $(0.00755)$ & & $(0.00942)$ & $(0.0121)$ & $(0.00807)$ & & $(0.00903)$ & $(0.00808)$ & $(0.00776)$ & & $(0.00940)$ & $(0.0182)$ \\
\hline \multirow[t]{2}{*}{ Commodityprice_pch } & & $0.0561^{* * *}$ & $0.0314^{* *}$ & $0.0282^{* *}$ & & $0.0451^{* * *}$ & $0.0241^{*}$ & $0.0291^{* *}$ & & $0.0222^{*}$ & 0.00262 & -0.00673 & & $0.0552^{* * *}$ & $0.0382^{* * *}$ & $0.0279^{* *}$ \\
\hline & & $(0.0119)$ & $(0.0119)$ & $(0.0124)$ & & $(0.0121)$ & $(0.0129)$ & $(0.0133)$ & & $(0.0129)$ & $(0.0153)$ & $(0.0156)$ & & $(0.0131)$ & $(0.00954)$ & $(0.0119)$ \\
\hline \multirow[t]{2}{*}{ L.RGDP_EM_growth } & & $0.0988^{* *}$ & -0.0396 & -0.0399 & & 0.00976 & $-0.120^{* *}$ & & & 0.0530 & $-0.0896^{*}$ & & & $0.0896^{*}$ & -0.0551 & -0.0153 \\
\hline & & $(0.0439)$ & $(0.0551)$ & $(0.0600)$ & & $(0.0530)$ & $(0.0530)$ & & & $(0.0508)$ & $(0.0530)$ & & & $(0.0448)$ & $(0.0417)$ & $(0.0445)$ \\
\hline \multirow[t]{2}{*}{ Global_bank_leverage } & & & & $0.0682^{* *}$ & & & & & & & & & & & & 0.0569 \\
\hline & & & & $(0.0335)$ & & & & & & & & & & & & $(0.0516)$ \\
\hline \multirow{2}{*}{ TED } & & & & $-0.527^{* *}$ & & & & & & & & & & & & $-0.778^{* *}$ \\
\hline & & & & $(0.261)$ & & & & & & & & & & & & $(0.292)$ \\
\hline US 10 bond yield & & & & & & & & $-0.240^{*}$ & & & & & & & & 0.0382 \\
\hline \multirow{2}{*}{ L.EMBI_growth } & & & & & & & & $0.0330^{*}$ & & & & & & & & -0.00357 \\
\hline & & & & & & & & $(0.0165)$ & & & & & & & & $(0.0139)$ \\
\hline L.MSCl_growth & & & & & & & & & & & & $0.0153^{* *}$ & & & & 0.0195 \\
\hline Observations & 50 & 50 & 50 & 50 & 50 & 50 & 50 & 50 & 50 & 50 & 50 & 50 & 50 & 50 & 50 & 50 \\
\hline R-squared (overall) & 0.660 & 0.415 & 0.710 & 0.731 & 0.510 & 0.238 & 0.569 & 0.580 & 0.396 & 0.091 & 0.421 & 0.436 & 0.643 & 0.468 & 0.733 & 0.789 \\
\hline R-squared (push variables) & 0.660 & - & 0.477 & 0.477 & 0.510 & - & 0.420 & 0.330 & 0.396 & - & 0.363 & 0.327 & 0.643 & - & 0.454 & 0.381 \\
\hline R-squared (pull variables) & - & 0.415 & 0.233 & 0.234 & - & 0.238 & 0.149 & 0.144 & - & 0.091 & 0.058 & 0.026 & - & 0.468 & 0.279 & 0.227 \\
\hline R-squared (type variables) & - & - & - & 0.021 & - & - & - & 0.106 & - & - & - & 0.083 & - & - & - & 0.181 \\
\hline
\end{tabular}

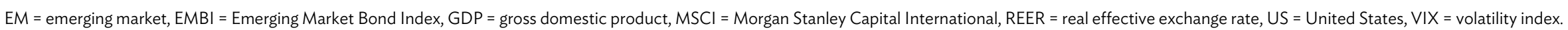

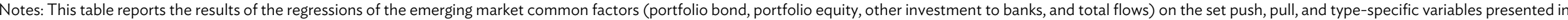

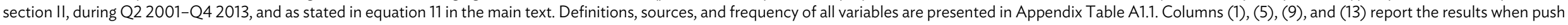

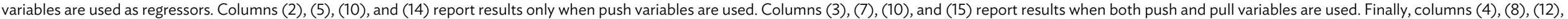

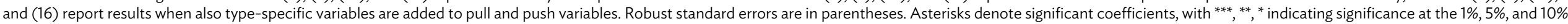
level, respectively. R-squared at the group level are calculated based on the Shapley decomposition.

Source: Authors' estimates. 


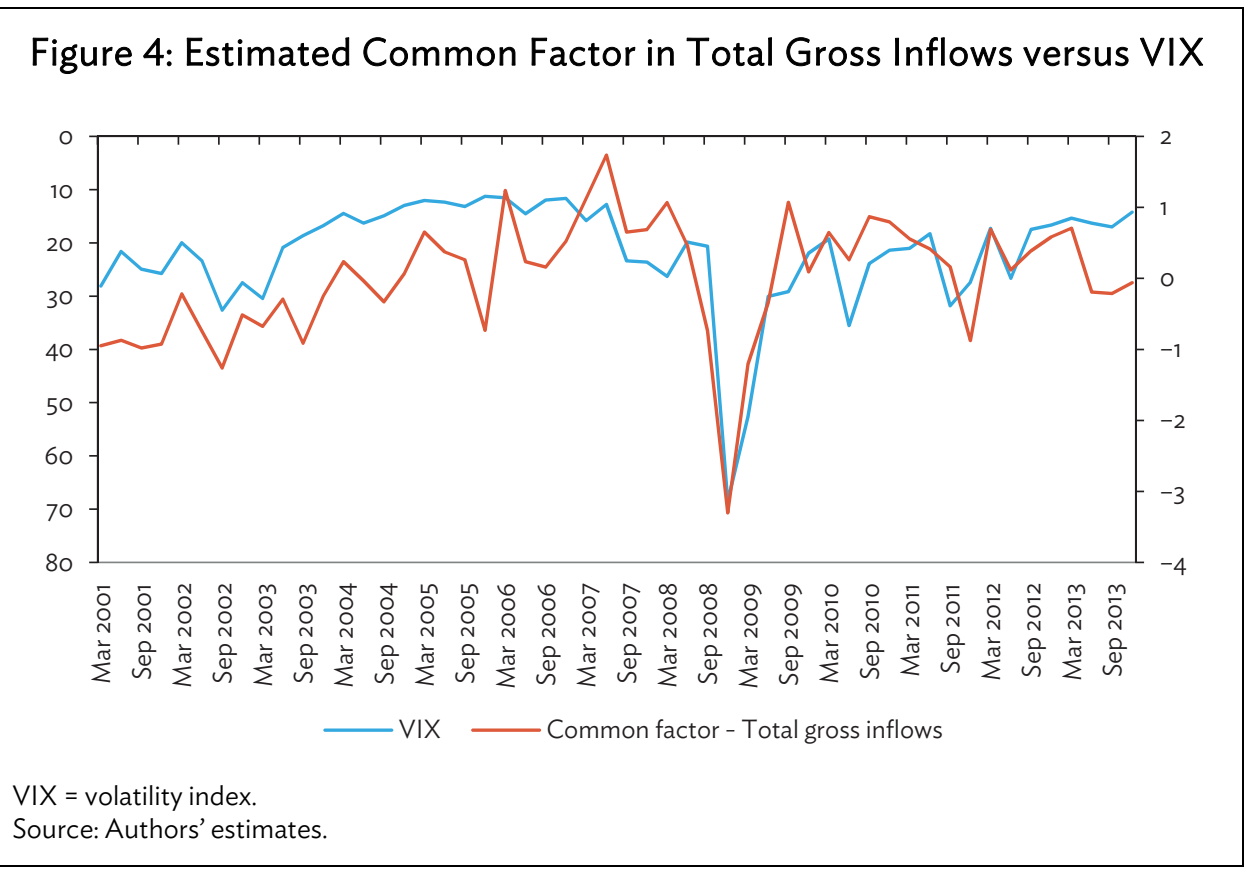

In terms of explanatory power, we find that push factors dominate pull factors, even when assetspecific variables are included in the regressions (see columns 4, 8, 12, and 16), even though the latter themselves are also statistically significant and with the expected sign. As reported in the group level $R^{2} s$, push factors account for about $65 \%$ of the overall $R^{2} s$ in the case of Ol banks, about $60 \%$ of the $R^{2} s$ for portfolio bonds, and about $75 \%$ in the case of portfolio equity flows. In sum, the analysis of the drivers of the EM common dynamic clearly indicate that, as expected, various global push variables play a major role, but with the relative importance of some factors varying across types of flows.

\section{What Drives the Impact of Global Push Factors across Countries?}

Next, we investigate what makes a country more sensitive (or immune) to changes in push factors. Why do some countries always gain (or lose) more inflows relative to other countries when conditions in core countries change? We take an agnostic approach and investigate whether macroeconomic and institutional fundamentals or financial market characteristics might explain such heterogeneity. In practice, this means that we regress the estimated factor loadings $\beta_{i}^{E M}$ for each asset (separately) on our two sets of fundamental-related and market-structure-based variables introduced in Section II (see further Appendixes A and B for a thorough discussion of the variables). The following cross-sectional regression is estimated for each type of flow separately:

$$
\beta_{i}^{E M}=\alpha . \text { Fundamentals }_{i}+\beta . \text { Market characteristics }_{i}+\varepsilon_{i}
$$

Before turning to our key findings, we acknowledge that our benchmark regression results are subject to some limitations. By construction, estimations are based on a small sample of 34 crosscountry observations (for each asset). Given the sample size, using all (14) fundamental-related and market-structure-based variables at once is practically infeasible. To overcome these constraints, we use the following strategy: we first regress the $\beta_{i}^{E M}$ on the fundamentals and market variables separately. We then combine variables that are significant in each category (if any) in one regression. To confirm that this procedure yields stable results, a Bayesian Model Averaging exercise is performed in the next 
section. At this point however, we emphasize that all results presented below are very robust to the issue of model uncertainty.

Table 5 provides the benchmark results, which are as follows. First, for the case of equity and bank flows, higher betas do not coincide with weaker fundamentals such as lower growth, higher debt, or poor institutions (columns 1-3 and 7-9). ${ }^{12}$ As far as bond flows are concerned (columns 4-6), we find that countries with higher reserves, higher trade openness, and more flexible foreign exchange regimes are more sensitive to global push factors. Second, we find that our proxies for the importance of global investors (international mutual funds in the case of equity and bond flows, and global banks in the case of $\mathrm{OI}$ to bank flows) are highly significant and suggest a potentially strong quantitative impact for all types of assets. For instance, we find that going from a zero to a perfect correlation increases the predicted response to a shock in the common EM factor by 0.45 for equity, 0.24 for bonds, and 0.75 for banks. Given the general levels of the betas, as also depicted in Figure 3, these are large effects. Third, equity markets that are more liquid (as measured by the turnover ratio) and belong to the MSCI Frontier Markets Index have a higher beta. Altogether, we also find that most of the cross-sectional variation in loadings can be explained by the market-related variables.

To sum up, the results show that EMs' sensitivity to the common dynamics varies across countries and type of flows; with the nature of the investor base having the more important role in explaining the cross-country differences in the case of equity and bank flows, and also, although to a lesser extent, in the case of bond flows. Macroeconomic fundamentals (e.g., foreign currency reserves, trade openness, and the type of exchange rate regimes) seem to be playing a key role in the case of bond flows. However, there is no robust evidence that good macroeconomic (e.g., public debt, growth) or institutional fundamentals (e.g., investment climate and rule of law) have a role in explaining EM different sensitivities to global push factors.

\section{Robustness}

This section provides some robustness checks. We first show that the estimated betas used in the regression are not only a reflection of the global financial crisis, but that they also reflect outcomes during other periods of sharp variations in global push factors. When comparing factor loadings with actual retrenchments in capital flows during the global financial crisis and the taper tantrum, we find that, in the overwhelming majority, countries with higher betas suffered a deeper retrenchment in flows in both episodes. This positive relationship is illustrated in Figure 5, which plots the beta coefficients for each asset on the y axis against the actual loss in funding experienced during the global financial crisis (left panel) and the taper tantrum (right panel). This finding shows that our approach is indeed capturing the actual sensitivity of most EM countries during periods of sharp movements in global push factors.

12 Only the bank flows measure seems to be sensitive to the choice of the exchange rate in column 7, but this result disappears once we control by market structure variables (column 9). 
Figure 5: The Model versus the Global Financial Crisis, and versus the Taper Tantrum
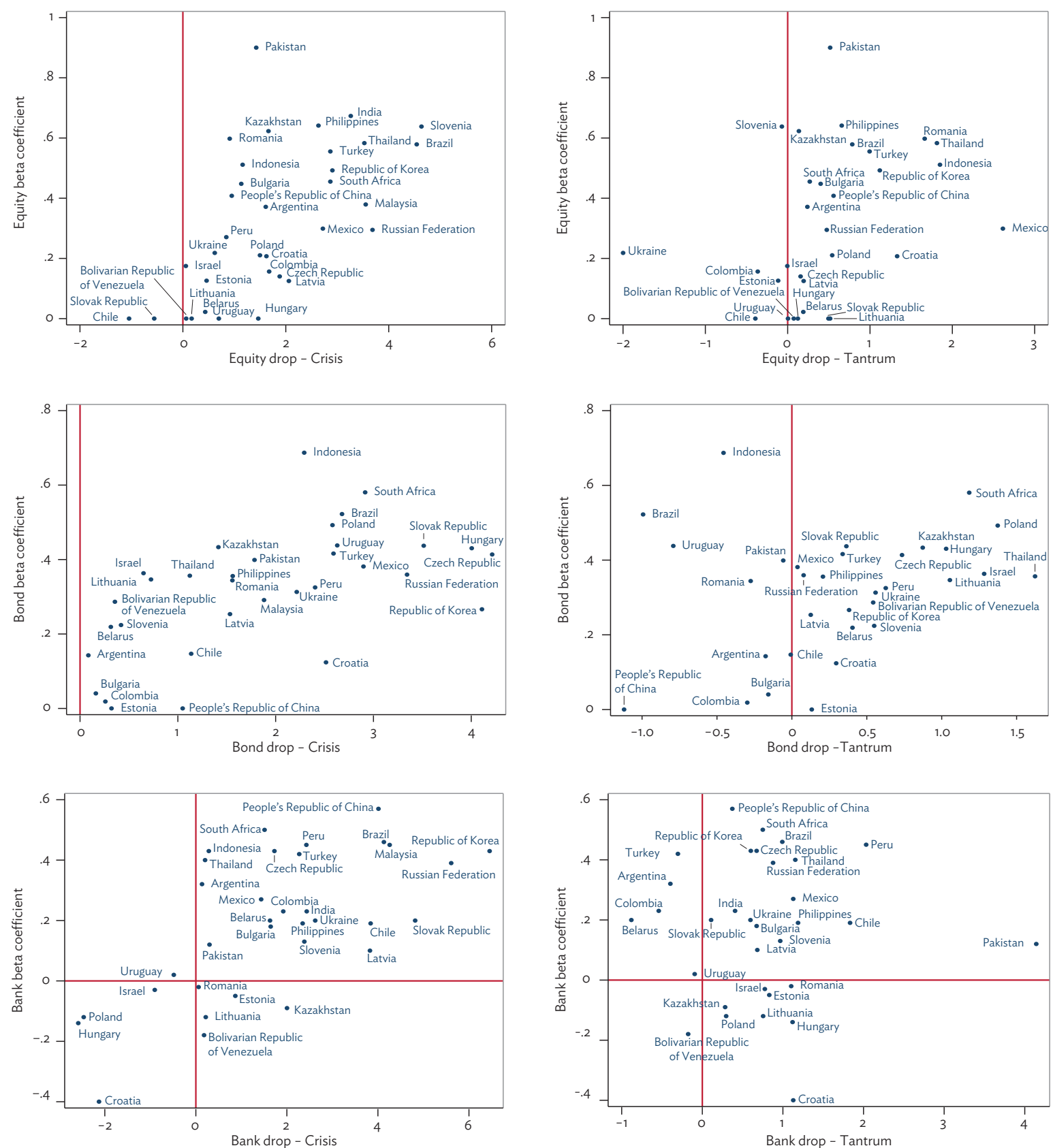

Notes: The left panel reports the cumulative drop in equity (bond or bank) inflows for each emerging market during the global financial crisis against the corresponding beta coefficient (on the $y$-axis, as presented in section III and Figure 4). The right panel plots the same beta coefficient against the cumulative drop experienced in any given asset during the taper tantrum episode. In the case of the global financial crisis, the cumulative drop is computed at the peak of the crisis, namely Q4 2007 and Q1 2008. In the case of the tantrum, because the retrenchment was experienced in June/July 2013 and was very short-lived, some countries experienced a dip in Q3 2013 whereas others were affected in Q4 2013 (or both). To circumvent this issue, we measure the cumulative drop over the taper tantrum as the minimum value among these two quarters. Note, however, that although the other procedure yield different quantitative assessment of the dip experienced, the general picture is invariant to the method chosen.

Source: Authors. 
Second, we demonstrate that the variables shown to be significant in the benchmark regression analysis are very robust to changes in covariates. Given the limited cross section at our disposal and the larger number of explanatory variables, the simple strategy we used to identify robust correlates might lead to misleading results. To address this issue of model uncertainty, we use a Bayesian Model Averaging (BMA) for each regression. ${ }^{3}$ In practice, BMA methods run the maximum combination of models and provide estimates and inference results that take into account the performance of the variable not only in the final reported model but over the whole set of possible specifications. After performing this robustness test, we find that the significant variables in the base regressions are always the most robust variables in the Bayesian averaging exercise (Table 6).

Third, we find that institutional fundamentals are not themselves driving the importance of global investors (fund or bank) in our sample. In particular, one could expect that countries with strong institutional fundamentals attract more global investors to begin with. As a result, the correlation variables that we found to be significant could be an indirect proxy for the quality of local institutions. However, we do not find any relation between the correlations used in the previous sections and the institutional quality of recipient markets, as measured by the value of the law and order and investor protection metrics computed by the International Country Risk Guide (Figure 6).

13 From a technical point of view, the BMA technique used here follows Fernandez, Ley, and Steel (2001). 
Table 5: Explaining Countries' Sensitivities to Push Factors

\begin{tabular}{|c|c|c|c|c|c|c|c|c|c|}
\hline & \multicolumn{3}{|c|}{ Equity Beta } & \multicolumn{3}{|c|}{ Bond Beta } & \multicolumn{3}{|c|}{ Bank Beta } \\
\hline & (1) & (2) & (3) & (4) & (5) & (6) & (7) & (8) & (9) \\
\hline \multicolumn{10}{|l|}{ Fundamentals } \\
\hline Trade openness & -0.000236 & & & $0.00179^{* *}$ & & $0.00110^{* *}$ & 0.000708 & & \\
\hline Debt/GDP & 0.00163 & & & 0.00193 & & & -0.00104 & & \\
\hline Reserves/GDP & 0.00190 & & & -0.00450 & & $-0.00559^{* * *}$ & 0.00567 & & \\
\hline FX regime & 0.0192 & & & $0.0315^{* * *}$ & & $0.0203^{* *}$ & $0.0342^{* *}$ & & 0.00766 \\
\hline Average growth & 0.0508 & & & 0.0122 & & & 0.0486 & & \\
\hline Investor protection & -0.0114 & & & -0.00423 & & & 0.000348 & & \\
\hline Law and order & -0.0199 & & & -0.0256 & & & -0.0696 & & \\
\hline \multicolumn{10}{|l|}{ Market Characteristics } \\
\hline Foreign openness & & 0.000124 & & & 0.00281 & & & -0.00306 & \\
\hline Local market size (\% of GDP) & & 0.000714 & & & & & & 0.000733 & \\
\hline Relative market size & & -0.00328 & & & 0.00608 & & & & \\
\hline MSCI EM benchmark (dummy) & & -0.0648 & & & 0.0233 & & & & \\
\hline MSCl frontier benchmark (dummy) & & $0.228^{* * *}$ & $0.242^{* * *}$ & & & & & & \\
\hline Turnover ratio & & $0.00176^{* * *}$ & $0.00170^{* * *}$ & & & & & & \\
\hline Share of funding from $A E$ & & 0.00167 & & & 0.00108 & & & & \\
\hline Correlation with EPFR (or BIS) flows & & $0.474^{* * *}$ & $0.454^{* * *}$ & & $0.260^{* *}$ & $0.241^{* *}$ & & $0.705^{* * *}$ & $0.75^{* * *}$ \\
\hline Constant & 0.0123 & -0.0369 & 0.0637 & -0.0130 & 0.110 & 0.101 & -0.207 & 0.146 & 0.0994 \\
\hline R-squared & 0.244 & 0.546 & 0.521 & 0.409 & 0.288 & 0.429 & 0.324 & 0.520 & 0.530 \\
\hline
\end{tabular}

$\mathrm{AE}=$ advanced economy, $\mathrm{BIS}=$ Bank for International Settlements, $\mathrm{EM}=$ emerging market, $\mathrm{EPFR}=$ Emerging Portfolio Fund Research, $\mathrm{FX}=$ foreign exchange, $\mathrm{GDP}=$ gross domestic product, $\mathrm{MSCl}=$ Morgan Stanley Capital International.

Notes: This table presents the results of the estimation of the regression of emerging market sensitivities in each type of flow on the set of macro, institutional, and market characteristics presented in section II, Appendix A, and Appendix B. Definitions, sources, and frequency of all variables are presented in Appendix Table A1.1. Columns (1), (4), and (7) report the results when only macroeconomic and institutional fundamentals are used as regressors. Columns (2), (5), and (8) report results only when market characteristics are used. Finally, columns (3), (6), and (9) report results when using as regressors the variables that are found significant in each subgroup. For a robustness check of this approach and corresponding results, see section IV.

Source: Authors. 
Table 6: Bayesian Averaging Results

\begin{tabular}{|c|c|c|c|c|c|c|c|c|c|c|c|}
\hline Equity-Bayesian Averaging & Coef. & t-stat & PIP & Bond-Bayesian Averaging & Coef. & t-stat & PIP & Bank-Bayesian Averaging & Coef. & t-stat & PIP \\
\hline Trade/GDP & 0.000 & -0.17 & 0.09 & Trade/GDP & 0.000 & 0.30 & 0.15 & Trade/GDP & -0.041 & -0.79 & 0.47 \\
\hline Debt/GDP & 0.000 & 0.04 & 0.07 & Debt/GDP & 0.000 & 0.24 & 0.12 & Debt/GDP & -0.024 & -0.4 & 0.21 \\
\hline FX regime & 0.002 & 0.29 & 0.13 & FX regime & 0.019 & 1.34 & 0.73 & FX regime & 0.048 & 0.19 & 0.12 \\
\hline Average growth & 0.008 & 0.43 & 0.22 & Average growth & -0.001 & -0.14 & 0.10 & Average growth & -0.017 & -0.05 & 0.1 \\
\hline Investor protection & -0.003 & -0.27 & 0.13 & Investor protection & 0.000 & -0.05 & 0.09 & Investor protection & -0.129 & -0.2 & 0.12 \\
\hline Local equity size & 0.000 & 0.17 & 0.09 & & & & & Private credit/GDP & 0.027 & 0.52 & 0.29 \\
\hline Relative equity size & 0.000 & 0.07 & 0.08 & Relative market size & 0.000 & 0.13 & 0.10 & & & & \\
\hline MSCI benchmark (dummy) & 0.000 & -0.01 & 0.09 & EMBI benchmark (dummy) & 0.007 & 0.25 & 0.12 & & & & \\
\hline MSCI frontier benchmark (dummy) & 0.184 & 1.48 & 0.77 & & & & & & & & \\
\hline Turnover ratio & 0.001 & 1.45 & 0.77 & & & & & & & & \\
\hline
\end{tabular}

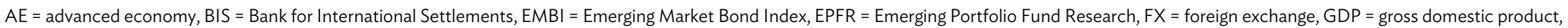
$\mathrm{MSCl}=$ Morgan Stanley Capital International, $\mathrm{OI}=$ other investment, $\mathrm{PIP}=$ post-inclusion probability.

Notes: Given our limited cross section, standard regression methods could fail to select robust relations. To address this issue and confirm the significance of the variables highlighted in section III, we use a

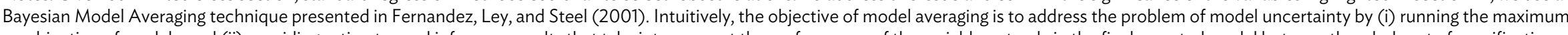
combination of models, and (ii) providing estimates and inference results that take into account the performance of the variable not only in the final reported model but over the whole set of specifications. In practice, these two steps boil down to estimate a parameter of interest conditional on each model in the model space and computing the unconditional estimate as a weighted average of the conditional estimates. This Table 6 reports the results of the Bayesian Averaging obtained for the equity, bond, and bank regressions presented in section III.C. Along with coefficient and t-statistics, it reports individual

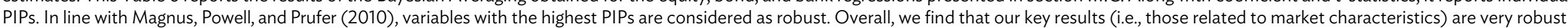
to the variation in the set of regressors.

Source: Authors' estimates. 


\section{Figure 6: Institutional Quality versus Correlations}
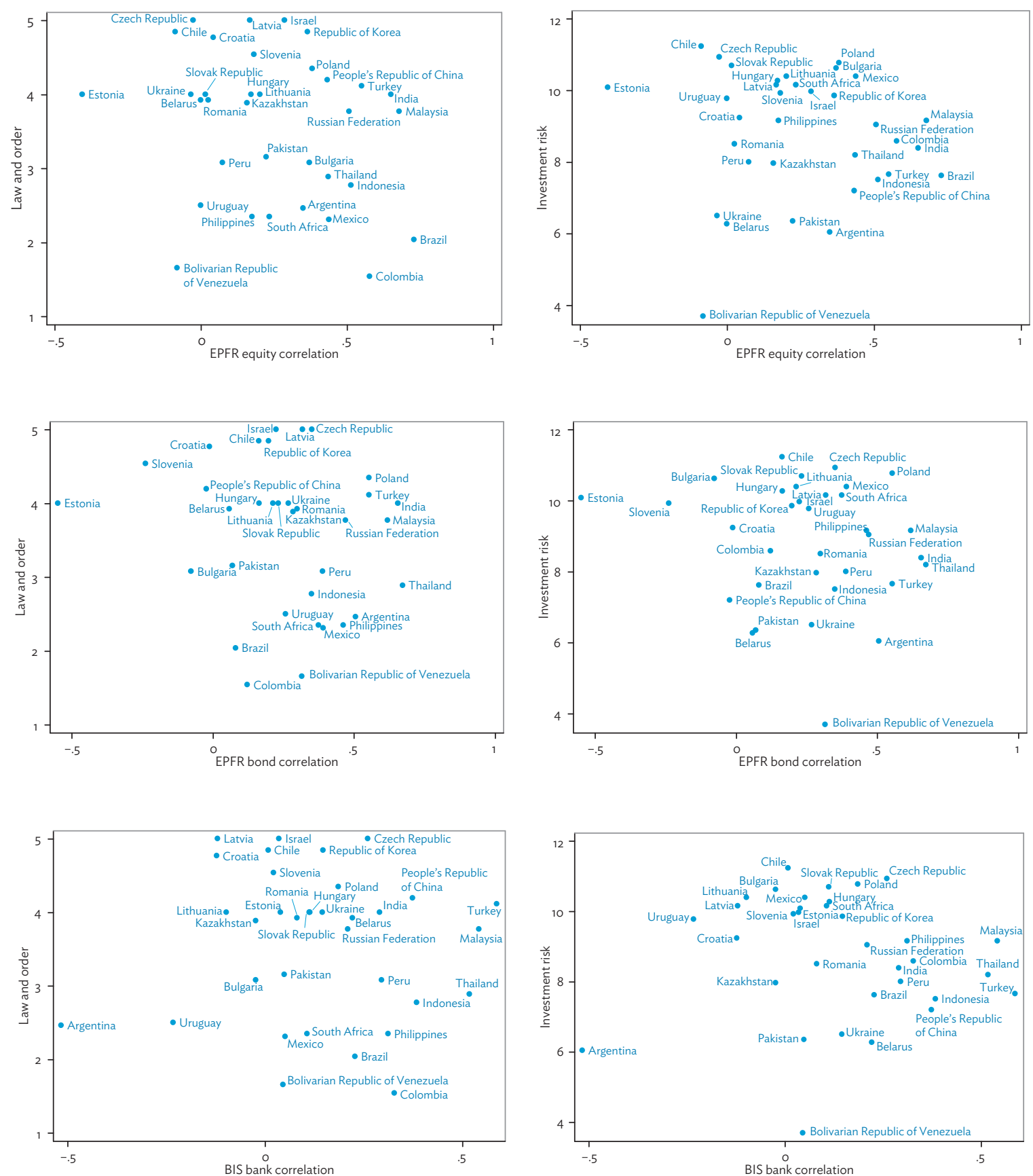

$\mathrm{BIS}=$ Bank for International Settlements, BOP = balance of payments, EPFR = Emerging Portfolio Fund Research, ICRG = International Country Risk Guide.

Notes: Figure 6 plots the proxies used for institutional quality against the BOP correlation with EPFR and BIS flows computed for each country in our sample. We use the ICRG law and order and investor protection ratings to proxy for institutional quality. The first, second, and third panel reports are dedicated to equity, bond, and bank correlations respectively.

Source: Authors. 


\section{CONCLUSION AND POLICY IMPLICATIONS}

After analyzing the sensitivity of 34 EMs to global push factors, we find that the cross-country differences in EM sensitivities to global push factors are, to a great extent, a function of market characteristics. In particular, the nature of a country's foreign investor base (the larger the role of international mutual funds in the case of equity and bond flows, and global banks in the case of bank inflows) explains the higher sensitivity of some EMs to global push factors. Macroeconomic fundamentals, in particular the type of foreign exchange regime, seem to be playing a key role in explaining cross-country sensitivities; but only in the case of bond flows. Last, but not least, we do not find evidence that institutional fundamentals (e.g., investor protection, rule of law) or standard measures of macroeconomic performance (higher growth, lower debt) have a role in explaining EM different sensitivities to global push factors.

Although these results have potentially important implications for EMs, they require careful interpretation. First, we emphasize that our findings do not mean that borrowers' fundamentals do not matter in shaping other crucial properties of capital flows to EMs. As a number of contributions have convincingly shown (e.g., Alfaro, Kalemli-Ozcan, and Volosovych 2008), countries with macroeconomic or institutional deficiencies tend to receive less capital inflows, a result we confirm in our EM sample. Different from this level effect, however, our findings suggest that the traditional push factor debate may have overstated the importance of fundamentals in shaping sensitivities to external shocks, at the expense of other important determinants. In other words, good fundamentals do not assure a country's insulation from global financial shocks. From a policy perspective, this implies that authorities in EMs should put effort into collecting information about their foreign investor base and the role of large funds (or asset management companies) in it. While systematic and reliable information on the decomposition of foreign holdings by type of investors is still insufficient, despite recent efforts (see for instance Arslanalp and Tsuda 2014), our analysis already shows that some measures can be created and used to assess countries' sensitivities.

Finally, we emphasize that further research is needed to understand the final macroeconomic impact of push factors at the country level. Although some countries might be highly sensitive to push factors, a number of parameters could dampen the overall impact of such waves of positive (or negative) inflows. For instance, the presence of a large pool of domestic investors absorbing the assets from foreigners leaving the country in times of stress could mitigate the final price and overall financial and economic impacts of sudden pressure in flows. A notable example among EMs in this respect is Malaysia, which is found to be sensitive to push factors in all assets in our analysis, but where negative inflows in times of stress are usually offset by local institutional investors repatriating foreign assets (IMF 2013b). Examination of the discrepancies between how flows and asset prices react to global push factors, and of the connected local institutional setup, constitute useful avenues that we leave for further research. 


\section{APPENDIXES}

\section{Appendix A. Details on Market Structure Variables}

Since not all variables are applicable (or available) for all assets classes, we provide below a summary of the variables chosen to proxy for these dimensions, as well as their definition. Sources are presented in Appendix Table A1.1.

- $\quad$ Foreign Openness and size measures are based on stock variables and are used to proxy for the amount of foreign funding received and the size of the local market. To distinguish between the local and the relative size of a given market, the stock of foreign equity (or bond) in any given country is normalized (i) by the GDP of the recipient market, and (ii) by the total of foreign equity (or bonds) into the 34 EMs considered in this paper.

- $\quad$ Liquidity measures are standard and rely on trading data when available. For equity markets, we use the turnover ratio, measured by the total value of shares traded every year divided by the average market capitalization. Because trading statistics are not available for all 34 bond markets on a consistent basis, we proxy for the liquidity of bond markets by creating a dummy variable which captures the membership of country to the key EM benchmarks - the JPMorgan Emerging Market Bond Index (EMBI) for bonds and the MSCI Emerging Markets Index for equities.

- The Composition of the Foreign Investor Base captures two characteristics of the lender profile of EMs. First, we control for the source of funds by computing the share of the total stock of foreign equity (or bond) funding that is coming from advanced economies. ${ }^{14}$ Second, we proxy for the importance of international funds and international (or global) banks in the foreign investor base. Because a decomposition of BOP stocks or flows by type of lender type is not available, we compute, for each country in our sample, the correlation between BOP-recorded equity (or bond) flows and EPFR-recorded flows, which capture flows from mutual funds in advanced economies to (or out of) emerging markets (EMs). For bank flows, we use BIS locational statistics and compute the correlation between BOP-recorded bank flows and BIS- recorded flows. In both cases, we interpret a high correlation as a sign that funds and global banks account for most of the movements in capital flows to and from any given economy. For details on EPFR and BIS data sets, their coverage and how they relate to BOP-recorded flows, see Appendix B.

14 This includes G10 countries as well as key financial or offshore centers (Luxembourg, Ireland, Cayman, Barbados, Bahamas, Guernsey, and Jersey). 


\section{Table A1.1: Variable Definitions, Frequency, and Sources}

\begin{tabular}{|c|c|c|c|}
\hline Variable & Definition & Frequency & Source \\
\hline \multicolumn{4}{|l|}{ Capital Flows } \\
\hline Capital inflows & $\begin{array}{l}\text { Gross inflow as \% GDP, total and by } \\
\text { component }\end{array}$ & Quarterly & $\begin{array}{l}\text { IMF Balance of Payment } \\
\text { Statistics }\end{array}$ \\
\hline Global bank flows & Inflow as \% GDP & Quarterly & $\begin{array}{l}\text { Bank of International } \\
\text { Settlements-Locational } \\
\text { Statistics }\end{array}$ \\
\hline Mutual fund flows & Inflow as $\%$ GDP & Quarterly & EPFR \\
\hline
\end{tabular}

Push/Pull factor analysis

\begin{tabular}{llll}
\hline Real GDP growth & $\begin{array}{l}\text { In \%, QoQ, unweighted average of } \\
\text { the US, euro area, Japan, and the UK }\end{array}$ & Quarterly & IMF WEO \\
\hline US VIX & CBOE S\&P500 Volatility VIX & Quarterly & Datastream \\
\hline $\begin{array}{l}\text { Expected change } \\
\text { in policy rate }\end{array}$ & $\begin{array}{l}\text { Difference between policy rate and } \\
\text { 30-day Federal funds 6-month futures }\end{array}$ & $\begin{array}{l}\text { Quarterly, average of } \\
\text { monthly figures }\end{array}$ & $\begin{array}{l}\text { Datastream and } \\
\text { Cleveland Fed }\end{array}$ \\
\hline US yield curve & 10 year/3 month US Treasury yield spread & Quarterly & Datastream \\
\hline US REER & US real effective exchange rate & Quarterly & IMF WEO \\
\hline Commodity prices & Growth rate, QoQ & Quarterly & IMF WEO \\
\hline US dealer bank leverage & (Equity+Total liabilities)/Equity & Quarterly & US Fund Flows \\
\hline US TED spread & 3-month TED spread (LIBOR- & Quarterly & Datastream \\
\hline 10Y bond yield & Treasury bill) & Quarterly & Datastream \\
\hline MSCI returns & Return in the MSCI EM index & Quarterly & Datastream \\
\hline EMBI returns & Return in EMBI index & Quarterly & Datastream \\
\hline
\end{tabular}

Macroeconomic and Institutional fundamentals

\begin{tabular}{|c|c|c|c|}
\hline Trade openness & (Export + Import)/GDP & $\begin{array}{l}\text { Average over } \\
2001-2013\end{array}$ & $\begin{array}{l}\text { World Development } \\
\text { Indicators }\end{array}$ \\
\hline FX regime $^{*}$ & Index from 1 to 13 & $\begin{array}{l}\text { Average over } \\
2001-2013\end{array}$ & $\begin{array}{l}\text { Ilzetzki, Reinhart, and } \\
\text { Rogoff (2004) }\end{array}$ \\
\hline Public debt & as $\%$ GDP & $\begin{array}{l}\text { Average over } \\
2001-2013\end{array}$ & $\begin{array}{l}\text { World Development } \\
\text { Indicators }\end{array}$ \\
\hline Reserves & as $\%$ GDP & $\begin{array}{l}\text { Average over } \\
2001-2013\end{array}$ & $\begin{array}{l}\text { World Development } \\
\text { Indicators }\end{array}$ \\
\hline Real GDP growth & $\%$, annual & $\begin{array}{l}\text { Average over } \\
2001-2013\end{array}$ & $\begin{array}{l}\text { World Development } \\
\text { Indicators }\end{array}$ \\
\hline Rule of law* & Index from 1 to 10 & $\begin{array}{l}\text { Average over } \\
2001-2013\end{array}$ & ICRG \\
\hline Investor protection* & Index from 1 to 10 & $\begin{array}{l}\text { Average over } \\
2001-2013\end{array}$ & ICRG \\
\hline
\end{tabular}

Market Characteristics

\begin{tabular}{llll}
\hline Foreign openness & $\begin{array}{l}\text { Stock of foreign equity, bond, or bank } \\
\text { claims/GDP }\end{array}$ & $\begin{array}{l}\text { Average over } \\
2001-2013\end{array}$ & IIP \\
\hline $\begin{array}{l}\text { Stock market } \\
\text { capitalization }\end{array}$ & Stock market capitalization/GDP & $\begin{array}{l}\text { Average over } \\
2001-2013\end{array}$ & World Bank Financial \\
& & & Development Database \\
\hline
\end{tabular}


Table A1.1 continued

\begin{tabular}{|c|c|c|c|}
\hline Variable & Definition & Frequency & Source \\
\hline $\begin{array}{l}\text { Bond market } \\
\text { capitalization }^{* *}\end{array}$ & Bond market capitalization/GDP & $\begin{array}{l}\text { Average over } \\
2001-2013\end{array}$ & $\begin{array}{l}\text { World Bank Financial } \\
\text { Development Database }\end{array}$ \\
\hline Private credit & Bank credit to the private sector/GDP & $\begin{array}{l}\text { Average over } \\
2001-2013\end{array}$ & $\begin{array}{l}\text { World Bank Financial } \\
\text { Development Database }\end{array}$ \\
\hline Stock market turnover & $\begin{array}{l}\text { Sum of all shares traded over the period / } \\
\text { Stock market capitalization }\end{array}$ & $\begin{array}{l}\text { Average over } \\
2001-2013\end{array}$ & $\begin{array}{l}\text { World Bank Financial } \\
\text { Development Database }\end{array}$ \\
\hline $\begin{array}{l}\text { Share of funding coming } \\
\text { from AEs }\end{array}$ & $\begin{array}{l}\text { Sum of bond (equity) coming from AEs and } \\
\text { financial centers } \\
\text { fundi*/Total bond (equity) }\end{array}$ & $\begin{array}{l}\text { Average over } \\
2001-2013\end{array}$ & CPIS \\
\hline $\mathrm{MSCI} \mathrm{EM}$ & $\begin{array}{l}\text { Country listed in the } \mathrm{MSCl} \text { emerging index } \\
\text { over the sample period }\end{array}$ & Dummy & Morgan Stanley \\
\hline $\mathrm{MSCI} F M$ & $\begin{array}{l}\text { Country listed in the MSCI frontier market } \\
\text { index over the sample period }\end{array}$ & Dummy & Morgan Stanley \\
\hline EMBI EM & $\begin{array}{l}\text { Country listed in the EMBI emerging index } \\
\text { over the sample period }\end{array}$ & Dummy & JP Morgan \\
\hline
\end{tabular}

$\mathrm{AE}=$ advanced economy, $\mathrm{CBOE}=$ Chicago Board Options Exchange, $\mathrm{CPIS}=$ Coordinated Portfolio Investment Survey, $\mathrm{EMBI}=\mathrm{Emerging}$ Market Bond Index, EM = emerging market, EPFR = Emerging Portfolio Fund Research, $F M=$ frontier market, $F X=$ foreign exchange, GDP = gross domestic product, ICRG = International Country Risk Guide, IIP = International Investment Position, IMF = International Monetary Fund, $\mathrm{LIBOR}=$ London Interbank Offered Rate, $\mathrm{MSCl}=$ Morgan Stanley Capital International, $\mathrm{Q} \circ \mathrm{Q}=$ quarter on quarter, $\mathrm{REER}=$ real effective exchange rate, UK = United Kingdom, US = United States, VIX = volatility index, WEO = World Economic Outlook. Notes:

* In the case of ICRG ratings, a higher value of the index indicates better institutions. For the foreign exchange regime, a higher value implies a more flexible exchange rate.

** Bond market capitalization data are not available for all countries in the sample. When used on the restricted sample however, the bond market capitalization is not found significant.

*** See Table 1 for the list of source countries.

Source: Authors' compilation. 
Table A1.2: Raw Statistics

\begin{tabular}{|c|c|c|c|c|c|}
\hline Variables & Obs & Mean & Std. Dev. & Min & Max \\
\hline \multicolumn{6}{|l|}{ Fundamentals } \\
\hline Trade openness & 34 & 80.52 & 41.22 & 23.99 & 187.30 \\
\hline Public debt & 34 & 40.69 & 19.08 & 5.95 & 79.21 \\
\hline Reserves & 34 & 19.58 & 9.37 & 6.96 & 44.33 \\
\hline Exchange rate regime & 34 & 8.29 & 3.04 & 2.00 & 13.00 \\
\hline Average growth & 34 & 4.76 & 1.73 & 0.78 & 9.94 \\
\hline Investor protection & 34 & 8.83 & 1.73 & 3.69 & 11.23 \\
\hline Rule of law & 34 & 3.59 & 1.01 & 1.54 & 5.00 \\
\hline \multicolumn{6}{|l|}{ Equity Market Characteristics } \\
\hline Foreign openness - Equity & 34 & 6.88 & 7.01 & 0.07 & 24.59 \\
\hline Relative market size - Equity & 34 & 2.94 & 4.66 & 0.00 & 17.36 \\
\hline Stock market capitalization & 33 & 43.19 & 40.52 & 0.49 & 190.54 \\
\hline MSCI EM country & 34 & 0.59 & 0.50 & 0.00 & 1.00 \\
\hline MSCI FM country & 34 & 0.29 & 0.46 & 0.00 & 1.00 \\
\hline Stock market turnover & 33 & 49.59 & 59.50 & 0.96 & 226.99 \\
\hline Share of equity funding from advanced economies & 34 & 67.19 & 22.72 & 12.48 & 95.67 \\
\hline BOP equity correlation with EPFR flows & 34 & 0.24 & 0.26 & -0.41 & 0.73 \\
\hline \multicolumn{6}{|l|}{ Bond Market Characteristics } \\
\hline Foreign openness - Bond & 34 & 10.04 & 6.48 & 0.12 & 30.47 \\
\hline Relative market size - Bond & 34 & 2.94 & 4.22 & 0.00 & 19.27 \\
\hline EMBI country & 34 & 0.65 & 0.49 & 0.00 & 1.00 \\
\hline Share of bond funding from advanced economies & 34 & 67.27 & 16.74 & 23.25 & 92.09 \\
\hline BOP bond correlation with EPFR flows & 34 & 0.26 & 0.26 & -0.55 & 0.67 \\
\hline \multicolumn{6}{|l|}{ Banking Market Characteristics } \\
\hline Foreign openness - Other investment & 34 & 36.29 & 19.08 & 4.32 & 96.40 \\
\hline Private credit/GDP & 32 & 63.39 & 29.11 & 24.57 & 138.60 \\
\hline BOP OI-Bank correlation with BIS flows & 34 & 0.13 & 0.22 & -0.52 & 0.59 \\
\hline
\end{tabular}

$\mathrm{BIS}=$ Bank for International Settlements, $\mathrm{BOP}=$ balance of payments, $\mathrm{EM}=$ emerging market, $\mathrm{EMBI}=$ Emerging Market Bond Index, EPFR = Emerging Portfolio Fund Research, FM = frontier market, GDP = gross domestic product, $\mathrm{MSCl}=$ Morgan Stanley Capital International, $\mathrm{OI}=$ other investment.

Source: Authors' estimates. 


\section{Appendix B. Balance of Payments Flows, EPFR Fund Flows, and BIS Banking Flows}

This appendix presents the key properties of the other capital flows data set based on dealer data used in this paper, the EPFR global data set and BIS locational banking statistics, and their connection with BOP-recorded flows. In both cases, we argue that using the correlation between each of these data sets and its counterpart in the BOP statistics approximates well the importance of such intermediaries in driving capital flows to emerging markets.

To proxy for the importance of funds (in particular, mutual funds) in driving portfolio flows recorded in the BOP, we use the EPFR Global data set. EPFR Global tracks the performance and asset allocation of a vast number of equity and debt funds domiciled in developed countries and important offshore financial centers. Over time, its coverage has increased significantly, and now reaches a wide range of industries and territories. As of 2013, the EPFR global was collecting information from more than 29,000 equity funds and 18,000 fixed-income funds, representing $\$ 20$ trillion of assets invested in over 80 mature and emerging markets.

As a result of its extensive coverage and quality, ${ }^{15}$ EPFR Global has been widely used in recent seminal contributions about funds behavior, in particular in the country flows format used in this paper (e.g., Raddatz and Schmukler 2012; Jotikasthira, Lundblad, and Ramadorai 2012; Fratzscher 2011; and others). In particular, given that most of the funds followed by the EPFR Global data set are located in advanced economies and account for a significant share of the external funding received by EMs, the country flows data set has proved to be a good (high frequency) proxy of total gross inflows in (or out) of emerging economies. For instance, Miao and Pant (2012) show that EPFR fund flows correlate well with BOP-recorded capital flows into emerging markets, thereby suggesting that when funds play an important role in the foreign investor base of a given country, EPFR flows act as a timely and accurate proxy for overall portfolio flows.

On the other hand, two important methodological issues prevent us from simply retrenching EPFR flows from BOP-recorded flows to assess the importance of funds. First, EPFR only covers a fraction of the mutual fund industry. Second, because EPFR fund flows are based on dealer transactions, recorded flows are not always consistent with the residency criteria used to record transactions in the BOP data. For instance, when a fund dedicated to India and located in the US sells an Indian bond to another nonresident (which is not covered by EPFR), this sale is recorded as an outflow from India in the EPFR data, but does not generate a negative inflow in India's BOP. As a result, the discrepancy between BOP and EPFR flows can sometimes be large: for a thorough discussion, see Koepke and Mohammed (2014). Relying on the correlation, rather than share in gross inflows, allows us to circumvent these issues.

To proxy the importance of global banks in driving nonresident gross inflows to banks, as recorded in the BOP, we use the BIS International Banking Statistics. These track internationally active banks' foreign positions through two main data sets: the BIS Consolidated Banking Statistics and the BIS Locational Banking Statistics (LBS). We use the BIS LBS instead of BIS Consolidated Banking Statistics because the first data set provides data following the same residency principle as the one used in BOP data; see Cerutti et al. (2012) for further details). LBS captures the cross-border positions of all banks-

15 The EPFR data set has been found to be a reliable data source. Comparing total net assets and monthly returns of a subsample of EPFR funds to the Centre for Research in Security Prices mutual fund data, Jotikasthira, Lundblad, and Ramadorai (2012) found only minor differences between EPFR and the Centre for Research in Security Prices data sets. See Puy (2013) for a thorough discussion of EPFR data set. 
defined as deposit-taking corporations, except the central bank in the Balance of Payments Manual (BPM6)-domiciled in the reporting area (about 40 countries, mostly advanced economies and financial centers), including gross position vis-à-vis their foreign affiliates, against borrower countries.

From the LBS data, based on publicly available data, it is possible to breakdown how much are the gross inflows going to the banking and nonbanking sector of each borrower country. The evolution of the global banks' claims (as reported by BIS) against the banking sector of each borrower country in our sample is the series that we correlate with OI to banks in order to define the correlation variable used as proxy for the composition of the foreign investor base. Since LBS largely reflects the position of prominent international banking centers (e.g., Minoiu and Reyes 2013 find that the top globally connected lenders in the LBS data set are banks operating in Belgium, France, Germany, Japan, Switzerland, the United Kingdom, and the US) we interpret a high correlation between the selected LBS series and $\mathrm{OI}$ to banks in a given EM country as signaling a larger activity of global banks in that borrower country. In addition to global banks, BOP figures also include nonbanks and banks located outside BIS reporting countries (e.g., the People's Republic of China) as lenders. 


\section{REFERENCES}

Adrian,Tobias, and Hyun Song Shin. 2014. "Procyclical Leverage and Value-at-Risk." Review of Financial Studies 27 (2): 373-403.

Aizenman, Joshua, Mahir Binici, and Michael M. Hutchison. 2014. "The Transmission of Federal Reserve Tapering News to Emerging Financial Markets.” NBER Working Paper No. 19980.

Alfaro, Laura, Sebnem Kalemli-Ozcan, and Vadym Volosovych. 2008. "Why Doesn't Capital Flow from Rich to Poor Countries? An Empirical Investigation." Review of Economics and Statistics 90 (2): 347-68.

Arslanalp, Serkan, and Takahiro Tsuda. 2014. "Tracking Global Demand for Advanced Economy Sovereign Debt.” IMF Economic Review 62 (3): 430-64.

Broner, Fernando, Tatiana Didier, Aitor Erce, and Sergio L. Schmukler. 2013. "Gross Capital Flows: Dynamics and Crises." Journal of Monetary Economics 60 (1): 113-33.

Bruno, Valentina, and Hyun Song Shin. 2015a. "Cross-Border Banking and Global Liquidity." Review of Economic Studies 82 (2): 535-64.

_ 2015b. "Capital Flows and the Risk-Taking Channel of Monetary Policy." Journal of Monetary Economics 71 (C): 119-32.

Calvo, Guillermo A., Leonardo Leiderman, and Carmen M. Reinhart. 1993. "Capital Inflows and Real Exchange Rate Appreciation in Latin America: The Role of External Factors." IMF Staff Papers 40 (1): 108-51.

_.1996. "Inflows of Capital to Developing Countries in the 1990s." Journal of Economic Perspectives $10(2): 123-39$.

Cerutti, Eugenio, and Stijn Claessens. 2014. "The Great Cross-Border Bank Deleveraging: Supply Side Characteristics and Intra-Group Frictions.” IMF Working Paper WP/14/180.

Cerutti, Eugenio, Stijn Claessens, and Patrick McGuire. 2012. "Systemic Risks in Global Banking: What Available Data Can Tell Us and What More Data Are Needed?” NBER Working Paper No. 18531.

Cerutti, Eugenio, Stijn Claessens, and Lev Ratnovski. 2014. "Global Liquidity and Drivers of Cross-Border Bank Flows." IMF Working Paper WP/14/69.

Cetorelli, Nicola, and Linda S. Goldberg. 2012a. "Liquidity Management of U.S. Global Banks: Internal Capital Markets in the Great Recession.” Journal of International Economics 88 (2): 299-311.

_. 2012b. “Banking Globalization and Monetary Transmission.” Journal of Finance 67 (5): 1811-43.

Chuhan, Punam, Stijn Claessens, and Nlandu Mamingi. 1998. "Equity and Bond Flows to Asia and Latin America: The Role of Global and Country Factors." Journal of Development Economics 55 (2): 439-63. 
Claessens, Stijn, and Neeltje Van Horen. 2014. “Foreign Banks: Trends and Impact.” Journal of Money, Credit, and Banking 46 (1): 295-326.

Eichengreen, Barry, and Poonam Gupta. 2014. "Tapering Talk: The Impact of Expectations of Reduced Federal Reserve Security Purchases on Emerging Markets." World Bank Policy Research Working Paper No. 6754.

Fernandez, Carmen, Eduardo Ley, and Mark F. J. Steel. 2001. "Benchmark Priors for Bayesian Model Averaging.” Journal of Econometrics 100 (2): 381-427.

Forbes, Kristin J., and Francis E. Warnock. 2012. “Debt- and Equity-Led Capital Flow Episodes.” NBER Working Paper No. 18329.

Fratzscher, Marcel. 2011. "Capital Flows, Push versus Pull Factors and the Global Financial Crisis.” ECB Working Paper No. 1364.

Fratzscher, Marcel, Marco Lo Duca, and Roland Straub. 2013. "On the International Spillovers of U.S. Quantitative Easing.” DIW Berlin Discussion Papers 1304.

Ghosh, Atish R., Mahvash S. Qureshi, Jun II Kim, and Juan Zalduendo. 2014. "Surges." Journal of International Economics 92 (2): 266-85.

Ilzetzki, Ethan O., Carmen M. Reinhart, and Kenneth Rogoff. 2004. "Exchange Rate Arrangements into the 21st Century: Will the Anchor Currency Hold?." Unpublished.

International Monetary Fund (IMF). 2013a. "Global Impact and Challenges of Unconventional Monetary Policies." Background paper. Washington, DC.

_ 2013b. "The Yin and Yang of Capital Flow Management: Balancing Capital Inflows with Capital Outflows." In World Economic Outlook, Chapter 4, Fall, by Jaromir Benes, Jaime Guajardo, Damiano Sandri, and John Simon.

Jotikasthira, Chotibhak, Christian Lundblad, and Tarun Ramadorai. 2012. "Asset Fire Sales and Purchases and the International Transmission of Funding Shocks." Journal of Finance 67 (6): 2015-50.

Koepke, Robin. 2014. "Fed Policy Expectations and Portfolio Flows to Emerging Markets." IIF Working Paper, May, Washington, DC.

_ 2015. "What Drives Capital Flows to Emerging Markets: A Survey of the Empirical Literature." IIF Working Paper, April, Washington DC.

Koepke, Robin, and Saacha Mohammed. 2014. “Portfolio Flows Tracker FAQ.” IIF Research Note.

Kose, Ayhan, Christopher Otrok, and Charles H. Whiteman. 2003. "International Business Cycles: World, Region, and Country-Specific Factors." American Economic Review 93 (4): 1216-39.

Magnus, Jan R., Owen Powell, and Patricia Prufer. 2010. "A Comparison of Two Model Averaging Techniques with an Application to Growth Empirics." Journal of Econometrics 154 (2): 139-53. 
Miao, Yanliang, and Malika Pant. 2012. "Coincident Indicators of Capital Flows." IMF Working Paper WP/12/55.

Milesi-Ferretti, Gian-Maria, and Cedric Tille. 2011. "The Great Retrenchment: International Capital Flows during the Global Financial Crisis.” Economic Policy 26 (66): 285-342.

Minoiu, Camelia, and Javier A. Reyes. 2013. “A Network Analysis of Global Banking: 1978-2010.” Journal of Financial Stability 9 (2): 168-84.

Prachi, Mishra, Kenji Moriyama, Papa M’B. P. N'Diaye, and Lam Nguyen. 2014. "Impact of Fed Tapering Announcements on Emerging Markets." International Monetary Fund and the Reserve Bank of India. Mimeo.

Puy, Damien. 2013. "Institutional Investors Flows and the Geography of Contagion." European University Institute Working Papers ECO 2013/06.

Raddatz, Claudio, and Sergio L. Schmukler. 2012. "On the International Transmission of Shocks: Microevidence from Mutual Fund Portfolios." Journal of International Economics 88 (2): 357-74.

Reinhart, Carmen M., and Vincent R. Reinhart. 2008. "Capital Flow Bonanzas: An Encompassing View of the Past and Present.” NBER Working Paper No. 14321.

Rey, Helene. 2013. "Dilemma not Trilemma: The Global Financial Cycle and Monetary Policy Independence." In Proceedings of the Federal Reserve Bank of Kansas City Economic Symposium at Jackson Hole.

Sahay, Ratna, Vivek Arora, Thanos Arvanitis, Hamid Faruqee, Papa N'Diaye, Tommaso Mancini-Griffoli, and an IMF Team. 2014. "Emerging Market Volatility: Lessons from the Taper Tantrum." IMF Staff Discussion Note SDN/14/09.

Shaghil, Ahmed, Brahima Coulibaly, and Andrei Zlate. 2014. "International Financial Spillovers to Emerging Market Economies: How Important Are Economic Fundamentals?" Board of Governors of the Federal Reserve System Working Paper D2015-37.

Shin, Hyun Song. 2012. "Global Banking Glut and Loan Risk Premium Mundell-Fleming Lecture." IMF Economic Review 60 (2): 155-92. 


\section{Push Factors and Capital Flows to Emerging Markets: Why Knowing Your Lender Matters More Than Fundamentals}

The paper analyzes the gross capital inflows' behavior across 34 emerging markets (EMs). It finds that aggregate inflows to EMs comove considerably, that countries relying more on international funds and global banks are more sensitive to push factors, and that EMs need to closely monitor their lenders and investors to assess their inflow exposures to global push factors. While global push factors in advanced economies mostly explain the common dynamics, their relative importance varies by type of flow. Meanwhile, the sensitivity to common dynamics varies significantly across borrower countries, affected strongly by market structure characteristics rather than their institutional fundamentals.

\section{About the Asian Development Bank}

ADB's vision is an Asia and Pacific region free of poverty. Its mission is to help its developing member countries reduce poverty and improve the quality of life of their people. Despite the region's many successes, it remains home to a large share of the world's poor. ADB is committed to reducing poverty through inclusive economic growth, environmentally sustainable growth, and regional integration.

Based in Manila, ADB is owned by 67 members, including 48 from the region. Its main instruments for helping its developing member countries are policy dialogue, loans, equity investments, guarantees, grants, and technical assistance. 